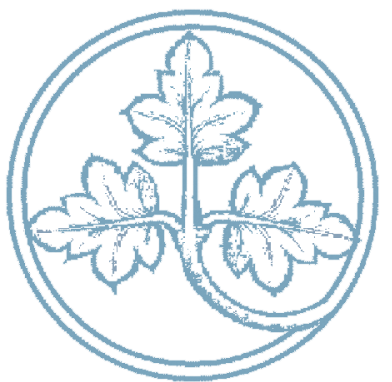

Interacting Product and Labor Market Regulation and the Impact of Immigration on Native Wages

Susanne Prantl

Alexandra Spitz-Oener

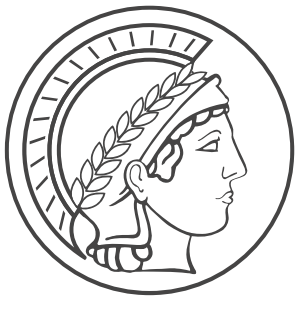




\title{
Interacting Product and Labor Market Regulation and the Impact of Immigration on Native Wages
}

October 2013

\author{
Susanne Prant] $]^{*}$ and Alexandra Spitz-Oener ${ }^{* *}$
}

\begin{abstract}
Does interacting product and labor market regulation alter the impact of immigration on wages of competing native workers? Focusing on the large, sudden and unanticipated wave of migration from East to West Germany after German reunification and allowing for endogenous immigration, we compare native wage reactions across different segments of the West German labor market: one segment without product and labor market regulation, to which standard immigration models best apply, one segment in which product and labor market regulation interact, and one segment covering intermediate groups of workers. We find that the wages of competing native West Germans respond negatively to the large influx of similar East German workers in the segment with almost free firm entry into product markets and weak worker influence on the decision-making of firms. Competing native workers are insulated from such pressure if firm entry regulation interacts with labor market institutions, implying a strong influence of workers on the decision-making of profit-making firms.
\end{abstract}

Keywords: Immigration, Product Market Regulation, Labor Market Regulation

JEL Classification: J61, L50, J3

*University of Cologne, Max Planck Institute for Research on Collective Goods, Bonn, and Institute for Fiscal Studies, London. E-mail: prantl@wiso.uni-koeln.de; Website: http://www.ieam.uni-koeln.de

**Humboldt-University Berlin, IAB, CASE and IZA. E-mail: alexandra.spitz-oener@wiwi.hu-berlin.de; Website: http://lvb.wiwi.hu-berlin.de/vwl/am.

We thank Philippe Aghion, Sandra Black, Leah Boustan, Christian Dustmann, Christoph Engel, Bernd Fitzenberger, Rachel Griffith, Martin Hellwig, Oliver Himmler, Jennifer Hunt, Pascal Langenbach, JörnSteffen Pischke, John Van Reenen, Jo Seldeslachts, Philipp Weinschenk, Joachim Winter, Max Steinhardt, Fabrizio Zilibotti, Christine Zulehner and seminar participants at the DIW Berlin, IZA Bonn, MPI Bonn, London School of Economics, University College London, Friedrich-Alexander-University Erlangen-Nürnberg, University of Amsterdam, University of Cologne, University of Frankfurt, University of Hamburg, University of Mannheim, University of Texas at Austin, University of Vienna, University of Zurich, ASSA Annual Meeting, EALE Conference, NORFACE Migration Conferences in London and Berlin, SOLE Annual Meeting, VfS Annual Conference and at the RES Annual Conference. Prantl gratefully acknowledges the hospitality of the Department of Economics at Harvard University where she worked on this project. Spitz-Oener gratefully acknowledges financial support from the German Research Foundation (DFG) through the Collaborative Research Centre (SFB) 649 "Economic Risk", through the Research Network "Flexibility in Heterogeneous Labor Markets" and through the NORFACE Research Programme on Migration in Europe. The data used in this paper were obtained from the German Zentralarchiv für Empirische Sozialforschung at the University of Cologne (ZA). The data were collected by the Bundesinstitut für Berufsbildung (BIBB) and the Institut für Arbeitsmarkt- und Berufsforschung (IAB), and documented by the ZA. Neither the producers of the data nor the ZA bear any responsibility for the analysis and interpretation of the data in the paper. 


\section{Introduction}

Advancing the understanding of how labor markets absorb economic shocks in the presence of product and labor market regulation is of general interest. In this paper, we focus on a positive labor supply shock and investigate how interacting product and labor market regulation determines native wage reactions to the shock. The comprehensive micro data evidence that we offer establishes the regulatory interaction as an important source of systematic heterogeneity in the responses of native wages to the large, sudden and unanticipated wave of migration from East to West Germany after German reunification. With this evidence, we contribute a new explanation for mixed findings in the previous immigration literature: ignoring interacting institutional settings can obscure immigration effects on native wages which could otherwise be observed.

Figure[1]illustrates the substantial influx of Germans from the former German Democratic Republic (named East Germans hereafter) onto the labor market of the Federal Republic of Germany (West Germany) after the sudden fall of the Berlin Wall on November 9, 1989, and the collapse of the German-German border. While less than 50,000 people per year came from East to West Germany before 1989, the numbers increased to about 400,000 per year in 1989 and 1990. Thereafter, the net inflow to West Germany flattened out and dropped below 50,000 per year after 1993:11

The internal migration wave after German reunification is ideally suited for our research purpose not only because of its magnitude and abruptness, but also for two more reasons. Firstly, East German migrants are more similar in many respects to native workers in West Germany than common immigrants.2 This fits well with standard immigration models where immigrant and native labor are treated as close substitutes in production ${ }^{3}$ These models provide the predictions for our benchmark case without regulation as product and labor markets are assumed to be perfectly competitive. In the competitive equilibrium real wages are determined by the marginal product of labor and the equilibrium wage falls

\footnotetext{
${ }^{1}$ See Burda and Hunt, 2001, Fuchs-Schündeln and Schündeln, 2009, Hunt, 2006, and Section 2.1.

${ }^{2}$ East Germans are Germans with full political and economic rights, have free access to the German labor market, face no language difficulties and are relatively well educated. See also Section 2.1.

${ }^{3}$ See Section 2.2, as well as Borjas, 1995, 1999, 2012, on further model assumptions.
} 
if newly arriving immigrants shift the labor supply curve outward. Secondly, the German reunification experiment provides us with an exceptional source of instrumental variation that we use to tackle potential endogeneity of immigration from East to West Germany in equations explaining native wages in West Germany. We focus on instrumental variable models where we identify immigration effects on the wages of medium-educated natives using data variation within occupation-age groups across time. Our instrumental variables measure the pool of medium-educated East Germans who exert an exogenous push effect on immigration into occupation-age-time cells of the West German labor market $\left.\right|^{4}$ These measures are constructed from comprehensive information on East Germans who migrated to West Germany, on those who stayed in East Germany and on the occupations in which these East Germans acquired their vocational training degrees before the collapse of the planned economy.

Our work differs from most empirical studies in the immigration literature due to its focus on the link between native wage responses to immigration and the regulatory background against which immigration occurs. Except for Angrist and Kugler (2003), earlier studies hardly take institutions explicitly into account.5 This is surprising given that the literature on the consequences of product market regulation for labor market outcomes and on interactions with labor market regulation goes back at least to Gersbach and Sheldon (1996) or Krueger and Pischke (1998). Empirical studies that neither consider immigration waves nor labor supply shocks, but the dependence of labor market outcomes on interactions between product and labor market regulation are more numerous. Examples include Fiori, Nicoletti, Scarpetta and Schiantarelli (2012), Griffith, Harrison and Macartney (2007), or Kugler and Pica (2006)

The theoretical model of Blanchard and Giavazzi (2003) provide us with one model component that is well-suited for deriving our hypothesis regarding the native wage response

\footnotetext{
${ }^{4}$ Medium-educated employees represent the dominant group of employees in the West German labor market, as well as the large majority of the East German migrants. See also Section 4.1 .

${ }^{5}$ In cross-country studies labor market institutions are, however, repeatedly referred to as a residual explanation for cross-country differences in labor market responses to immigration. See, among others, Antecol, Kuhn and Trejo, 2006, or Kahn, 2004.

${ }^{6}$ Aghion, Burgess, Redding and Zilibotti, 2006 and 2008, among others, also focus on interactions of product and labor market regulation, but not on labor market outcomes.
} 
to immigration of similar workers if product and labor market regulation exist simultaneously 7 If product market regulation causes high entry costs for firms and, thus, producing firms earn rents, then workers with high bargaining power due to suitable labor market regulation can obtain real wages surpassing their marginal product of labor. The resulting wedge should, in turn, disconnect the variation of native wages from wage pressure owing to an immigration shock which increases the supply of labor.

Given their interest in the role of institutions, Angrist and Kugler (2003) do not only report average effects of the immigrant share in the labor force on native employment, estimated on country-year panel data for European countries during the 1980s and 90s. They show, instead, that the negative, but often weak, average effects get more pronounced in country-years with higher labor market regulation, or higher product market regulation. Their empirical approach exploits the Balkan Wars as well-suited, exogenous shocks to immigrant flows in Europe for tackling with potentially endogenous immigration in equations explaining native labor market outcomes. They can, however, not distinguish between specific institutional mechanisms, and do not consider possibly relevant interactions between product and labor market regulation. Our research design moves ahead in this respect. We single out the segment of a country-specific labor market where product and labor market regulations interact and compare native labor market outcomes across labor market segments with different regulatory settings.

To separate between the relevant labor market segments, we rely on two core elements of German product and labor market regulation. Each element was implemented long before the labor supply shock that we consider, has matured decades ago and has a century-long history. One is the German Trade and Crafts Code - a product market regulation that substantially restricts firm entry in a clearly defined set of product markets, but not in others.8 The other is the German Works Constitution Act - a labor market regulation prescribing the rights and obligations of works councils and the conditions under which

\footnotetext{
${ }^{7}$ Blanchard and Giavazzi, 2003, assume monopolistic competition in the product markets, which determines the size of rents, and Nash bargaining between workers and their employers in the labor market, which determines the distribution of rents. See Section 2.2 for details.

${ }^{8}$ The regulated product markets account for about 40 percent of the employment in our main sample.
} 
works councils have to be installed in establishments.9 Works councils empower incumbent workers in the decision-making of firms and represent more than 90 percent of the employees in establishments with 50 or more employees 10

Our main empirical findings are in line with the expectations, based on standard immigration models and the relevant mechanism in Blanchard and Giavazzi (2003). The wages of native West Germans in the competitive labor market segment of the West German labor market respond negatively to the influx of similar workers from East Germany. In that segment, firm entry into product markets is almost free and workers' influence on firm decision-making is weak. It fits best with standard immigration models and covers 32.5 percent of the employment in our main sample. The segment-specific effect estimate suggests that the increase from zero to about four percentage points in the share of medium-educated East Germans that hit the West German labor market unexpectedly during the 1990s reduced the wages of competing native West Germans by about 6.26 percent. This is economically significant and reasonable, given that native wages in the competitive segment increased by 19.22 percent between 1986 and 1999. In contrast, native wages do not respond negatively to immigration in the labor market segment where product and labor market regulation exist simultaneously. Here, the restriction to firm entry into product markets and the worker-empowering labor market institution are strong. 17.4 percent of the employment in the main sample are covered ${ }^{11}$

Our analysis can be integrated well into several strands of the immigration literature which are in search of explanations for why the observed consequences of immigration on natives' labor market outcomes can be heterogeneous. A series of papers carves out that a low degree of substitutability between immigrants and natives can be an important reason for weak or even no effects of immigration on the wages of native workers (see, among others, Borjas, 2003, D'Amuri, Ottaviano and Peri, 2010, Manacorda, Manning

\footnotetext{
${ }^{9}$ Note that an establishment represents a line of business in a legally independent firm.

${ }^{10}$ These establishments cover about 45 percent of the employment in our main sample. See Table B.2 for the descriptive statistics in this paragraph and Section 3 for further details.

${ }^{11}$ For the intermediate segment where either strong product or strong labor market regulation are missing, but not both, we find - again in line with expectations - negative, but statistically insignificant effect estimates. That segment with either strong firm entry restrictions or strong worker influence, but not both, covers 50.1 of the employment in our main sample.
} 
and Wadsworth, 2012, and Ottaviano and Peri, 2012). Those studies focus on episodes and types of immigration that are distinct in structure from the specific labor supply shock that we analyze. Compared to the typical immigrant considered in these studies, East German migrants onto the West German labor market after German reunification are far more similar to native West German workers in their education class and occupation.

In line with theories of endogenous technological change, several other studies report producers adapting their production technologies in response to immigration. Lewis (2004), for example, revisits the Mariel Boatlift experiment, first analyzed by Card (1990). Lewis shows that industries in Miami adjusted to the influx of the mainly unskilled Marielitos by using more unskilled-intensive production technologies ${ }^{12}$ In a similar vein, Lewis (2011) documents how the elastic supply of automation machinery at a fixed price and changes to investment plans can shield the relative wages of low-skilled natives from the effect of immigration shocks to their relative supply. The German-German migration wave, in contrast, does not include workers of any education class over-proportionately. Hence, the educational distribution of German workers in West Germany remained stable. Peri (2012) and Peri and Sparber (2009) analyze adjustments along the occupational margin and show that immigration can cause natives to specialize in different production tasks, thereby reducing downward wage pressure. We document below that such adjustment process is also at work after the influx of East Germans to the West German labor market. However, we observe similar adjustment patterns in every segment of the labor market that we distinguish. Thus, differential adjustments across segments offer in our context no alternative to the institutional explanation that we postulate here.

The internal wave of East Germans migrating to West Germany after German reunification has already received attention in the literature, but our empirical approach differs in a number of important ways. First, we use comprehensive data on the region where individuals spent most of their youth in order to directly identify migrants from East to West Germany after reunification from native West Germans in the West German labor

\footnotetext{
${ }^{12}$ Bodvarsson, Van den Berg, and Lewer, 2008, investigate another specific adjustment process to the Mariel Boatlift experiment. Their findings suggest that the potential negative effect of immigration on native wages was dampened by the fact that immigrants consumed local goods and thereby increased labor demand in the sectors in which they predominantly found work.
} 
market. Second, the migrants who we identify include the numerous movers in the early years 1989, 1990 and 1991 (see Figure 1). Third, we develop the instrumental variable approach explained above to consider that immigration from East to West Germany may be endogenous in our equations explaining native wages in West Germany. D'Amuri et al. (2010), in contrast, treat the influx of East Germans onto the West German labor market from 1992 onwards as an exogenous source of instrumental variation when analyzing the effects of immigration in general on labor market outcomes of West Germans in West Germany. ${ }^{13}$ They find no adverse average effects on wages or employment. Frank (2009) investigates the impact of resident flows from East German counties to West German counties and finds neither effects on wages nor on medium-term employment of all residents in West Germany. Our work also differs in one additional respect from these studies: we recognize the relevance of product and labor market regulation - and, most importantly, their interaction - for the impact of immigration on native wages.

The paper is organized as follows. In the next section, we describe the labor supply shock and derive our hypotheses on native wage effects. The relevant product and labor market regulations follow in Section 3. We explain the empirical modeling in Section 4, and the data in Section 5. Section 6 covers the empirical results and we conclude in Section 7 .

\section{The Labor Supply Shock and Native Wages}

\subsection{German-German Migration after Reunification}

The large, unanticipated wave of migration from East to West Germany that followed the sudden fall of the Berlin Wall on November 9, 1989, and the collapse of the GermanGerman border, represents a major shock that increased labor supply in the West German labor market. East-West migration between 1989 and 1992 increased the West German population by 2.3 percent in net terms, and in the period up to 1999 by 2.8 percent 14

\footnotetext{
${ }^{13}$ Using data from the German Institute for Employment Research (IAB), they identify East Germans as individuals with German nationality who worked in East Germany in 1992 or later and subsequently started to work in the West. West Germans are identified as those who have German nationality and work in West Germany in all considered years (1987 to 2001).

${ }^{14}$ These population shares are based on administrative data from the Federal Statistical Office of Germany (Statistisches Bundesamt Deutschland). In 1989, the West German population aged 15 to 65 years was 42.9 million.
} 
Among German employees in the West German labor market, the share of East Germans was 3.2 percent at the beginning of 1992 and 4.1 percent at the beginning of 199915

Germany was divided for 45 years after World War II. East-West migration was common in the initial years after World War II and continued after the creation of the German Democratic Republic (GDR) in 1949. It became virtually impossible, however, after the building of the Berlin Wall in 1961. With its unexpected fall in 1989, East-West migration became straightforward again, and a massive wave of migration set in. As shown in Figure 1. about 400,000 people came from East to West Germany in 1989, with a similar figure for $1990{ }^{17}$ Thereafter, the net inflow to West Germany flattened out due to declining immigration and increasing emigration. After 1994, the gross flows were relatively stable and the net inflow to West Germany fell back to the level of before 1989, that is below 50,000 people per year ${ }^{18}$

The Germans who migrated after reunification from East to West Germany are distinct from common immigrants in a number of dimensions, and they are similar in many respects to native workers in West Germany. They are native speakers, facing no language difficulties ${ }^{19}$ They are also better educated and easier to integrate into the West German labor market for several reasons. One reason concerns the similarities between the vocational training systems in both parts of Germany dating back to their joint history before World War II. The reunification contract, furthermore, acknowledged all training degrees from the former GDR, and East German migrants were considered as Germans with full

\footnotetext{
${ }^{15}$ To calculate these employment shares, we use our main data source (see Section 5 . Note also, that East-West migration after German reunification caused no substantial shifts in the relative supplies of different types of native German workers in the West German labor market. Supporting descriptive statistics are provided in Appendix A and these compare well with those reported in D'Amuri et al., 2010, or Hunt, 2006.

${ }^{16}$ In the U.S., the immigrant share of total employment rose from 6.7 to 8.9 percent between 1980 and 1990, constituting the largest influx into the U.S. since the beginning of the 20th century (Jaeger, 2007).

${ }^{17}$ Migration of East Germans who fled their home country and reached West Germany indirectly, via Hungary and Austria in most cases, set in before the fall of the Berlin Wall. This is due to the fact that several Central and Eastern European countries bordering the GDR had lifted travel restrictions as early as 1988. The majority of the migrants in 1989, however, came directly from East to West Germany.

${ }^{18}$ See also Burda and Hunt, 2001, and Hunt, 2006, on German-German migration between 1957 and 1999, and Fuchs-Schündeln and Schündeln, 2009, on the time period up to 2006.

${ }^{19}$ Lewis, 2013, among others, highlights language skills as an important determinant of the degree of substitutability between natives and immigrants.
} 
political and economic rights in the Federal Republic of Germany (FRG) ${ }^{20}$ Finally, human capital accumulated in the GDR was transferable to the West German labor market (Fuchs-Schündeln and Izem, 2012, and Krueger and Pischke, 1995, among others).

Altogether, we focus on a wave of internal migration, like Boustan (2009) or Boustan, Fishback and Kantor (2010), for example. This is a key difference of our study, and those cited above, from studies that have analyzed the impact of immigrants from other source regions to the West German labor market in recent decades ${ }^{21}$ The specific characteristics of the internal migrants place the labor supply shock somewhere between a shock due to standard immigration from a foreign country and a shock due to shifts in the size of birth cohorts, or changes in female labor force participation (Acemoglu, Autor and Lyle, 2004, Welch, 1979).

\subsection{Hypotheses on Native Wage Effects}

The sudden wave of German-German migration after reunification provides a unique setting for investigating how a major immigration shock impacts the wages of competing native workers, depending on product and labor market regulation. We distinguish between three segments of the West German labor market, differing with regard to product and labor market regulation.

Our focus is on two polar segments. The first one, named the competitive segment, covers employees in product markets with almost free firm entry and in establishments with weak worker influence on the decision-making of firms 22 Standard models of the immigration literature fit well with that segment as product and labor markets are considered as competitive in these models (see, for example, Borjas 1995, 1999, 2012). Immigrant and native labor are considered perfect substitutes in production, fitting well with the specifics of the labor supply shock under consideration here: incoming East German mi-

\footnotetext{
${ }^{20}$ Other immigrants to Germany often have access only to restricted work permits or a potential employer has to prove that there is no German worker who could do the job instead.

${ }^{21}$ See, among others, Bonin, 2005, Brücker and Jahn, 2011, Glitz, 2012, Steinhardt, 2011, and Appendix A for further details.

${ }^{22}$ We consider market entry for new firms as being almost free in the product markets that are not under the product market regulation mentioned below. We choose this wording as there are several entry restrictions that apply to all product markets in Germany to a similar degree, such as various administrative costs (see, among others, Djankov et al., 2002).
} 
grants are closer substitutes in production to native West German workers than common immigrants. ${ }^{23}$ In the competitive equilibrium of such a model real wages are determined by the marginal product of labor. ${ }^{24}$ Newly arriving immigrants shift the labor supply curve outward and the equilibrium wage falls. As a result, our first expectation is:

1. In the competitive segment with almost free firm entry and weak worker influence on the decision-making of firms, a wave of worker immigration exerts downward pressure on the wages of competing native workers.

The second segment is the one in which product market regulation and labor market regulation are interacting. Product market regulation can restrict product market competition by many means, for example, by state involvement in production, tariffs, other trade barriers, or firm entry regulation. In our context, the firm entry regulation in the German Trade and Crafts Code is relevant. It restricts firm entry strongly in some product markets by imposing substantial fixed entry costs on entering firms, but not in others (see Section 3.1). In the product markets where firm entry is costly due to the firm entry regulation, product market competition is lower and profits are higher than in the other markets, even in the long run with an endogenous number of firms (Tirole, 1988). ${ }^{25}$ Labor market regulation can cause deviations from a competitive equilibrium outcome in various ways, for example, due to unemployment insurance, employment protection, or strong institutions representing worker interests. Works councils are the relevant institution in our context. These are regulated by means of the German Works Constitution Act and allow for a strong influence of workers on the decision-making of firms (see Section 3.2). Interactions of product and labor market regulation, and their consequences for labor market outcomes, are core components of the theoretical model of Blanchard and Giavazzi (2003). 26 Despite the fact that they address a different research question than we do,

\footnotetext{
${ }^{23}$ In addition, firms are assumed to maximize profits and produce goods using the following inputs: immigrant labor, native labor and capital. The production function is assumed to exhibit constant returns to scale and the supply of capital is perfectly inelastic.

${ }^{24} \mathrm{~A}$ firm responding to immigration by paying lower wages and keeping production constant might earn higher profits in the short term. Such profits, as well as profits coming from other sources, would, however, not persist in equilibrium in competitive product markets with free firm entry.

${ }^{25}$ Note that incumbent firms in standard models of product markets with positive entry costs don't have any incentive to grow until profits are fully eliminated.

${ }^{26}$ The work of Spector, 2004, Ebell and Haefke, 2009, Koeniger and Prat, 2007, or Seldeslachts, 2008, for example, is closely related.
} 
their theoretical framework is the adequate starting point for our study ${ }^{27}$ They assume monopolistic competition in the product markets, which determines the size of rents, and Nash bargaining between workers and their employers in the labor market, which determines the distribution of rents between firms and their workers. Product market regulation is assumed to cause entry costs for firms that enter a product market and to reduce competition among producing firms. Labor market regulation is modeled as increasing the bargaining power of workers. Given Nash bargaining and rents accruing due to entry costs, workers with high bargaining power can obtain real wages surpassing their marginal product of labor.

Using this set-up, straightforward implications follow for the labor market segment with product market regulation and labor market regulation in our context. Producing firms earn rents due to the substantial regulatory entry costs and workers have a strong influence on firms' decision making due to the role of works councils. The fact that the relevant product and labor market regulation exist simultaneously creates the opportunity for a wedge between real wages and the marginal product of labor. Such a weakening of the link between real wages and the marginal product of labor should, in turn, insulate incumbent native workers from wage pressure owing to a sudden immigration shock which increases the supply of labor. Accordingly, our second expectation is:

2. In the segment with both regulations which generate high firm entry costs and strong worker influence on firms' decision-making, the wages of incumbent native workers are prevented from falling in response to immigration of similar workers.

In addition to the two polar segments of the West German labor market, we also consider an intermediate one with two distinct groups of employees. The first group consists of employees in product markets with almost free firm entry and in establishments with strong worker influence on firms' decision-making. Despite the latter, the wedge between real wages and the marginal product of labor will be small as the chances for persistent profits tend to be low in product markets with almost free firm entry. ${ }^{28}$ The second

\footnotetext{
${ }^{27}$ Their focus is on the dynamic and distributional effects of the removal of the two forms of regulation in a general equilibrium context.

${ }^{28}$ In product markets with free firm entry, firms that try to pass on wage costs surpassing the marginal
} 
group covers the employees in product markets with strong firm entry restrictions and in establishments with only weak worker influence. Even though product markets with high firm entry costs allow for persistent profits, the worker influence is too weak to cause a noticeable wedge between real wages and the marginal product of labor. This leads to our third expectation:

3. In the intermediate segment, the response of natives' wages to immigration of similar workers will be negative as in the competitive segment, but possibly to a lesser degree.

\section{Product and Labor Market Regulation}

\subsection{Firm Entry Regulation}

The German Trade and Crafts Code (GTCC; Handwerksordnung, HWO) covers rules which impose substantial restrictions on firm entry into certain product markets, but not into others. The roots of the law go back to times long before World War II. In 1897, parts of the historical guild system in Germany became institutionalized as a first backlash to the introduction of the freedom of trade ("Gewerbefreiheit") in the German Reich in 1871. In 1908, the master craftsman certificate was imposed as requirement on individuals who wanted to train apprentices in one of the regulated occupations. In 1935, however, it gained a substantially different role: individuals who wanted to be registered so that they could start a legally independent business in one of the regulated product markets needed a relevant master craftsman certificate ${ }^{29}$ This regulatory change established a substantial firm entry regulation ${ }^{30}$ It was confirmed in the first post-war version of the West German Trade and Crafts Code of 1953, and the set of regulated product markets

product of labor to consumers by charging prices above marginal costs will be forced out of the market by entrants, or incumbent competitors. Accordingly, the chances are low for accruing profits that could be used for disentangling real wages and the marginal product of labor.

${ }^{29}$ The Nazi regime therewith picked up on a long-standing request of the German Trade and Crafts Organizations in an attempt to increase the support of the members of these non-Nazi organizations for their forced integration into the totalitarian Nazi system ("Gleichschaltung").

${ }^{30}$ See $\S 1$ and $\S 7 \mathrm{HWO}$, as well as Appendix A for further details. Note, in addition, that the firm entry regulation here is different from occupational licensing. It imposes restrictions on firm entry, and not on all individuals working in the regulated occupations. Under a licensing law, in contrast, it is illegal to work in the regulated occupation without meeting specific standards (see Kleiner, 2000, among others). 
remained stable until the end of the 1990s, our observation period. Similar regulation exists in other countries, for example in Austria, the Netherlands or Sweden, but the rules in Germany are particularly strict (Monopolkommission, 1998).

To acquire a master craftsman certificate, a person has to pass several consecutive stages of training, collecting work experience, and examination. Firstly, the individual needs a basic vocational training in a relevant occupation; this typically involves three years of apprenticeship training ("Lehre"). Secondly, the individual must pass the related journeyman examination, certifying the required skills for undertaking all occupationspecific tasks ("Gesellenprüfung"). The journeyman degree is the formal prerequisite for admission to the master exam ("Meisterprüfung"), with admission typically also requiring several years of work as a journeyman. Exam candidates usually also take part-time or full-time preparation courses lasting up to three years. The master exam covers general topics, i.e. law, book-keeping, controlling, marketing and human resource management, as well as occupation-specific fields. A regional committee of five members examines the master candidate in closed sessions and, during the 1980s, the candidates in about 25 percent of all exams failed (Deregulierungskommission, 1991) ${ }^{31}$ Altogether, earning a master craftsman certificate requires investing a substantial amount of time, in addition to paying, for example, course fees.

The German monopoly commission, as well as other German or EU institutions, have long criticized the restrictions on firm entry in the GTCC (Deregulierungskommission 1991, Monopolkommission 1998 and 2002). Most importantly, the regulation is argued to restrict entry, industry dynamics and competition, leading to higher product prices and lower production quantities 32

To distinguish the product markets with and without the firm entry regulation in the GTCC, we rely on the law enumerating all the occupations for which it regulates firm entry, on highly disaggregated data on the occupation of employees and on data on the em-

\footnotetext{
${ }^{31}$ Three members of the examination committee are from the same occupation as the candidate, with two of these being incumbent firm owners holding a master craftsman certificate.

${ }^{32}$ Increased market concentration and retailer prices are, for example, reported by Bertrand and Kramarz, 2002, for the case of a zoning regulation in the French retail trade industry that involves restrictions to firm entry. Prantl and Spitz-Oener, 2009, show that the firm entry regulation that we focus on lowered entry into self-employment during the 1990s. See Appendix A for further discussion.
} 
ployers' industry affiliation (see Section 5 for details). The set of product markets to which the firm entry regulation applies covers many occupations that were organized as guilds in the Middle Ages, along with various later additions (Boyer 1990, Deregulierungskommission 1991). The regulated product markets are in fields as diverse as metalworking, food, clothing and textiles, or cleaning services. More importantly, regulated product markets can be found in similar fields to unregulated ones: for example, confectionery, hairdressing, printing and bookbinding, and building cleaning are regulated, but ice cream production, beautician services, copy and paper production, and car cleaning are not.

The employer size distribution is remarkably similar in regulated and unregulated product markets, reflecting the fact that the regulation under investigation here restricts firm entry, but does not at the same time involve a direct firm size restriction 33 In line with expectations for effective restrictions to firm entry in the regulated product markets, we observe, however, a lower share of workers in micro establishments with less than 5 employees and a higher share in large establishments with more than 499 employees than in unregulated product markets (see Appendix B and Table B.1 for details). The average tenure of workers in the regulated product markets is 13.10 years which is 2.09 years higher than in the other product markets. This pattern is in line with less job creation and destruction due to reduced firm entry and reduced industry dynamics in the markets with firm entry restrictions, and it is in line with productive resources being more concentrated in incumbent firms.

\subsection{Works Councils}

The labor market institution of relevance in our context is the works council. Works councils constitute a core component of the German industrial relations system (see Appendix A for details and other components). The creation and embodiment of works councils, as well as their rights and obligations, are regulated in the German Works Constitution Act (Betriebsverfassungsgesetz, BetrVG). The first Works Constitution Act that was nationally binding in the Federal Republic of Germany came into effect in 1952, but the roots

\footnotetext{
${ }^{33}$ This is in contrast to the regulations studied, for example, by Bertrand and Kramarz, 2002, or Chari, 2011.
} 
of the law go back to the labor movement in the mid-1800s 34 The version of the law relevant to our observation period, the 1990s, dates back to 1972. Similar laws are also prevalent in other countries, most closely related are those in Austria, The Netherlands, Denmark, and Sweden.

The regulation regarding works councils determines, in particular, strong worker involvement in hiring, firing and pay scheme decisions. The institutional details are such that works councils must be set up in establishments with more than 5 employees if demanded by the work force ( $\S 1$ and $\S 4$ BetrVG), and the size of the works council then depends on the size of the establishment ( $§ 9$ BetrVG) ${ }^{35}$ Addison, Schnabel and Wagner (1997) show that about 92 percent of the employees in establishments with 50 or more employees are represented by works councils, while the figure is only 18 percent in those with less than 50 employees 36

The involvement of works councils in human resource measures, covering hiring and pay scheme decisions, is specified mainly in $§ 99$ BetrVG. A works council in an establishment with more than 20 employees must be involved in every single hiring decision. It needs to be informed in advance about the application documents, the person applying, the targeted position, the wage classification, the consequences of the hiring for the incumbent employees, and possible transfers of personnel associated with it. A works council can refuse to give its consent to a hiring, in particular, when there is a well-grounded concern that the new hiring might confront incumbent workers with firings, or other disadvantages $\left(\S 99(2)\right.$ BetrVG) ${ }^{37}$ In addition, a works council can object to proper notices of work contract termination if one of the conditions in $\S 102$ BetrVG are fulfilled 38

Similar rules regarding the information rights of works councils, as well as their involvement and potential mediation procedures, in $\S \S 111$ to 113 get relevant if a firm plans

\footnotetext{
${ }^{34}$ Before the 1950 s, there were various local laws that were typically binding for specific industries, for example the laws for mining in Bavaria and Prussia from 1900 and 1905, respectively.

${ }^{35}$ An establishment represents a line of business in a legally independent firm.

${ }^{36}$ Beckmann, Föhr and Kräkel, 2010, among others, report similar results using an alternative data source.

${ }^{37} \mathrm{~A}$ works council's refusal of consent can complicate a hiring substantially, for example through labor court involvement (§99(4) BetrVG).

${ }^{38}$ This can also complicate human resource management, and again through court involvement.
} 
to relocate, restructure or close an establishment. Works councils choose the members of the economic committee ("Wirtschaftsauschuss"), which is mandatory in firms with more than 100 employees $(\S 106(1)$ and $\S 107$ BetrVG). The management of the firm has to inform the committee in time about the current and expected economic and financial situation of the firm, while the committee, in turn, has to inform the works council ( $\$ 106(2$, 3) and $\S 108(4)$ BetrVG). Taken together, the representatives of incumbent workers in works councils have to be well informed about the firms' performance and prospective management strategies. Accordingly, they are aware of the profit situation, including the profit consequences of newly hired East German employees, and will only approve accompanying personnel measures when incumbent workers do not suffer as a result.

In our empirical analysis, we build on the empirical regularity reported by Addision et al. (1997), among others, to distinguish between establishments with weak and strong worker influence in firms' decision-making. Namely, we treat workers in small establishments with less than 50 employees as those with weak influence and workers in establishments with 50 or more employees as those with works council representation allowing for strong influence. As we want to identify how the interaction of firm entry restrictions with worker-empowering institutions impacts the native wage response to a labor supply shock, we use various approaches to capture alternative establishment size-effects on wage outcomes, and we also modify the size variation in our estimation sample (see Sections 4.1 and 6). Overall, we will demonstrate that the specifics of our empirical strategy allow us to capture work councils as the relevant labor market institution and to rule out alternatives to our explanation for our key empirical findings.

\section{Empirical Modeling}

\subsection{Model specifications}

Our empirical model is designed to identify the impact of interacting product and labor market regulation on the response of native workers' wages to a large labor supply shock. The main estimation equation allows for native wage responses to the unexpected inflow of similar workers that vary across regulation-specific segments of the labor market: 


$$
\log w_{i j g t}^{W}=\alpha+\beta^{C} m_{j g t}^{E} C_{j g t}+\beta^{B} m_{j g t}^{E} B_{j g t}+\beta^{I} m_{j g t}^{E} I_{j g t}+C_{j g t}+I_{j g t}+V+\nu_{i j g t},
$$

with

$$
V=\gamma^{C^{\prime}} X_{i j g t} C_{j g t}+\gamma^{B^{\prime}} X_{i j g t} B_{j g t}+\gamma^{I^{\prime}} X_{i j g t} I_{j g t}+\varrho_{j g}+\varsigma_{j t}+\tau_{g t}+\phi_{z t} .
$$

The main equation (1) expands the following basic equation:

$$
\log w_{i j g t}^{W}=\alpha+\beta m_{j g t}^{E}+\gamma^{\prime} X_{i j g t}+\varrho_{j g}+\varsigma_{j t}+\tau_{g t}+\phi_{z t}+\nu_{i j g t} .
$$

We estimate these equations using data on individuals from repeated cross-sections. The outcome variable is the logarithm of $w_{i j g t}^{W}$, the real hourly wage of a West German employee $i$ who works in the West German labor market in occupation $j$ and belongs to age group $g$ at time $t$. Our main explanatory variable, $m_{j g t}^{E}$, is the share of East Germans in the occupation-age-time cell $j g t$ of the West German labor market 59 The column vector $X_{i j g t}$ covers demographic and work-related characteristics of employees: a dummy for men, and quadratic polynomials in age and tenure ${ }^{40}$ To denote error terms, we use $\nu_{i j g t}$.

In the basic equation $2, \beta$ is the coefficient on the immigration measure $m_{j g t}^{E}$. Similar model specifications have often been used, for example by Borjas, 2003, or Friedberg, 2001. Our basic set-up differs from theirs by allowing for workers in different occupations, but within the same education-age group, to be imperfect substitutes in production. The reasons for this are twofold. Firstly, human capital is, in parts, occupation-specific 41 Secondly, the product market regulation of interest here defines product markets along the occupational dimension 42 We use the following six age groups: 25-29, 30-34, 35-39, 40-44, 45-49, and 50-54. We focus on employees with a medium level of education, holding a vocational training degree, either from the dual system of apprenticeship or a vocational school ${ }_{43}^{43}$ Medium-educated employees represent the dominant group of employees in each

\footnotetext{
${ }^{39}$ Alternatively, we use the corresponding absolute number of East Germans $E_{j g t}$.

${ }^{40}$ Column vectors of coefficients on $X_{i j g t}$-terms are indicated by $\gamma$.

${ }^{41}$ See Card, 2001, Gathmann and Schönberg, 2010, or Kambourov and Manovskii, 2009, on occupationspecificity of human capital.

${ }^{42}$ Note that we also use, in addition, an alternative industry-level measure. See Section 5

${ }^{43}$ The main characteristic of the German dual system of apprenticeship is that acquisition of human
} 
of the West German segments that we consider, as well as the large majority of the East German immigrants to the West German labor market44 We exclude highly educated individuals with a degree from a university or a technical college as these are too strongly clustered into a few occupations to be included in our empirical analysis (see Appendix B]. Since low education is defined as having no occupational training, we cannot construct the required instrumental variables for employees with low education and exclude these as well.

In the main equation 1, $C_{j g t}$ denotes the competitive segment with employees in product markets in which firm entry is almost free and in establishments in which workers' influence on the decision-making of firms is weak. This segment fits best with standard immigration models where product and labor markets are competitive (see also Section 2.2. Employees in segment $B_{j g t}$ face interacting product and labor market regulation, as the GTCC restricts firm entry and the German Works Constitution Act leads to strong influence of workers on firm decision-making. All other employees are in the intermediate segment $I_{j g t}$ with either strong entry restrictions or strong worker influence, but not both. We include the indicators for two of the three segments, $C_{j g t}$ and $I_{j g t}$, directly in equation (1). These variables control for any wage differences across the segments, including those following from different establishment size. To allow for immigration impacting natives' wages differently across segments, we interact the segment indicators with our immigration measure, $m_{j g t}^{E}$, and denote the segment-specific coefficients as $\beta^{C}, \beta^{B}$, and $\beta^{I}$. As explained in Section 2.2, we expect the estimate of $\beta^{C}$ to be negative and the estimate of $\beta^{I}$ to be similar to $\beta^{C}$, but weaker. In contrast, the estimate of $\beta^{B}$ should not be negative.

\subsection{Identification and Instrumental Variation}

We identify immigration effects on native wages using data variation within occupationage groups across time. The $\beta$-coefficients reflect the degree to which wage changes in occupation-age cells over time vary with the size of the influx of East Germans into capital consists of both on-the-job training and training in schools.

${ }^{44}$ In addition, the influx of East Germans after reunification did not change the educational distribution of German employees in West Germany. See Section 2.1 and Appendix A for details. 
the respective occupation-age cells in the same time period. Therefore, our individuallevel analysis is comparable to a change analysis at the group level, rather than a level analysis. The main advantage of using individual data instead of data at the occupationage-time level is having additional options for mitigating potential omitted variable biases. Suppose, for example, that the inflow of East Germans into occupation-age cells led to changes in the individual characteristics of West German employees in the cells that were hit, and that these changes differed across segments. To address the concern that such differences could be captured by the segment-specific effects of immigration which we observe, we allow for segment-specific effects of the vector of employee characteristics, $X_{i j g t}$, by interacting it with the three segment indicators.

All our estimation equations include occupation-age interactions $\varrho_{j g}$ to account for different permanent levels of native wages across occupation-age cells. Wage changes over time that are specific to occupations are captured by occupation-time interactions $\varsigma_{j t}$, while those specific to age groups are captured by age-time interactions $\tau_{g t}$. In addition, we include interactions between time and 2-digit employer industries $\phi_{z t}$ where industries are denoted by $z$. As we include the exhaustive sets of these four types of interactions we account for basic time, age-group, occupation and industry effects 45 The industry-time and occupation-time interactions address the concern of potential demand fluctuations hitting specific industries or occupations during the observation period. The industry-time interactions also capture potential time-varying effects of collective bargaining on wages, for example wage floors for some worker groups, in specific industries (see Appendix A.

The core identification issue that we address is endogeneity of immigration in equations explaining native wages. The two main sources of potential biases are East German migrants who may have self-selected into occupations in the West German labor market based on their anticipation of future profit and wage developments, and hiring decisions of employers that may have depended on similar expectations. Occupation-age, occupationtime and age-time interactions can, in parts, already account for endogenous decisions of immigrants and employers 46 In order to deal also with endogeneity resulting from

\footnotetext{
${ }^{45}$ In that respect, our equations are comparable to, among others, equation 3 in Borjas, 2003.

${ }^{46}$ Occupation-age interactions account for endogenous decisions of immigrants or employers based on
} 
immigrants and employers taking time-varying occupation-age-specific wage changes into account, we opt for an IV approach. East Germans may be attracted to occupations in West Germany for which they expect a positive shock and corresponding future wage increases in the age-class relevant to them. OLS estimates of the immigration effect on native wages would be upwardly biased in case of such positive covariance between the immigration and error terms, leading to an underestimation of a negative immigration effect on native wages. Alternatively, East Germans may be able to enter an occupationage cell more easily in the case of a negative shock accompanied by future wage decreases. Our instrument is a measure of the pool of East Germans who exert an exogenous push effect on occupation-age-time cells in the West German labor market. It is denoted by $p_{j g t}^{E}$ and defined as the number of all medium-educated employees who work in age-group $g$ in East or West Germany in time period $t$, who grew up in East Germany and who have a vocational training degree that is relevant for occupation $j$ and was acquired in GDR times. To construct the measure, we use data on East German employees who stayed in East Germany after reunification and on those who moved to West Germany. In addition, we take advantage of information on the occupations in which these East Germans received their vocational training degree 47 All East Germans with an educational degree relevant to occupation $j$ have, to some extent, human capital that is specific to occupation $j$ and this part of their human capital tends to be remunerated highly in occupation $j$. Accordingly, these East Germans are more likely to enter occupation $j$ in the West German labor market than other East Germans 48

The instrumental variation which we use follows from occupation-specific educational degrees that East Germans acquired in GDR times. We argue that it is uncorrelated with unobserved factors influencing West Germans' labor market outcomes for several reasons.

time-constant unobservable heterogeneity across occupation-age cells. Occupation-time and age-time interactions control for time-varying unobservable heterogeneity that is specific to either occupations or age groups.

${ }^{47}$ Using information on training occupations before reunification is inspired by Friedberg, 2001, who studies the effects of Russian immigrants on native labor market outcomes in Israel. She uses data on the movers' former occupations in Russia for instrumenting. We can, instead, use data on the vocational training of East German movers and stayers.

${ }^{48}$ If, for example, there were many East Germans at the age of 42 in 1992 who were trained as watchmakers in the GDR, we expect more immigration in the age group 40-44 in that occupation in West Germany at that time, relative to immigration in other occupation-age-time cells. 
Firstly, the fall of the Berlin Wall and German reunification came unexpectedly and migration from East to West Germany was effectively impossible in GDR times. Therefore, East Germans did not base their training decisions on the profits and earnings potential in occupations in West Germany. Note here that more than 90 percent of East German migrants in our main sample completed their vocational training in GDR times ${ }_{49}^{4}$ Secondly, the planned economy system of the GDR restricted individuals' training choice to increase social equality which was one of the political aims of the GDR vocational system. Accordingly, children and parents were encouraged not to choose the same occupation. Finally, the annual number of training positions per occupation depended on inflexible 5-year production plans and several ad-hoc changes to education policy. Altogether, East Germans were often prevented from choosing a vocational training in line with their preferences, and future developments in West Germany were irrelevant to the training allocation in the GDR.

We endogenize the terms $m_{j g t}^{E} * C_{j g t}, m_{j g t}^{E} * I_{j g t}$, and $m_{j g t}^{E} * B_{j g t}$ in Equation (1), estimating two-stage least square regressions. The straightforward approach is to interact the instrumental variable, $p_{j g t}^{E}$, with the indicators for the three segments, and to use the resulting interactions as excluded instruments (see Section 6.2 for an alternative approach). In any case, our identification of segment-specific immigration effects on native wages builds on the standard assumptions of IV models with one endogenous explanatory variable, and on the full set of instruments effecting immigration into the various segments differently.

\section{Data}

We use data from the "Qualification and Career Survey", which was carried out by the Research Institute of the Federal Employment Service (Institut für Arbeitsmarkt- und Berufsforschung, $I A B$ ) and the German Federal Institute for Vocational Training (Bundesinstitut für Berufsbildung, BIBB) ${ }^{50}$ For the purpose of our study, the survey waves of

\footnotetext{
${ }^{49}$ Assuming that East Germans completed their training at an age of about 16 years, the distribution is as follows: 10 percent undertook their training before 1960, 22 percent during the 1960s, 36 percent during the 1970s, 22 percent between 1981 and 1985, and 10 percent between 1986 and 1990.

${ }^{50}$ The data have been used, among others, by DiNardo and Pischke, 1997, Harhoff and Kane, 1997, and more recently by Dustmann, Ludsteck and Schönberg, 2009, or Spitz-Oener, 2006. Appendix B provides
} 
1986, 1992, and 1999 provide us with several unique advantages 51 The first advantage is the fact that we can directly identify native East and West German individuals who are employed either in the East or the West German labor market, using data on the region in which survey participants grew up in the past, on their current residence and their citizenship. This distinguishes our work from other recent studies on immigration in Germany 52 Secondly, detailed information on the occupation in which individuals worked when participating in the survey, as well as data on the industry affiliation of employers and entrepreneurs, are crucial for distinguishing between employees in product markets with the firm entry regulation of the GTCC and in those without it. Thirdly, we also know the occupation in which employees have been trained. This provides us with instrumental variation that is well suited for tackling the identification problem that arises due to potentially endogenous immigrant and employer decisions.

Our main sample consists of 17,776 observations on employees in the West German labor market before and after reunification. All these individuals grew up in West Germany, currently reside there, have German citizenship, are between 25 and 54 years old, work between 10 and 75 hours per week, and report the relevant data on employee and employer characteristics. They have medium education, as already explained in Section 4.1. and work in occupations that are covered by the dual system of apprenticeship and that have an official educational degree (staatlich anerkannte Ausbildungsberufe). These occupations are officially accredited by the Federal Ministry of Education and Research (Bundesministerium für Bildung und Forschung, BMBF) and the BIBB. Accredited training occupations account for about 85 percent of all medium-educated employees in our raw data. This is our population of interest, as the GTCC restricts firm entry into some accredited occupations, but not into others. ${ }^{53}$ We excluded employees in the public sector, non-profit organizations, the mining and quarrying sector and all small occupation-age-

details on the survey design.

${ }^{51}$ The data were collected during the winter months 1985/86, 1991/92 and 1998/99.

${ }^{52}$ Data sources providing only information on citizenship or nationality, for example, do not allow for identifying inter-regional migrants and natives in the East and West German labor markets, as all these individuals have German citizenship.

${ }^{53}$ Without this restriction, the main estimation results that we report in Section 6 remain robust. 
time cells with less than 5 employees ${ }^{54}$

Descriptive statistics on the main sample are provided in Table B.2 of Appendix B. The main variables for our empirical analysis are defined as follows ${ }^{55}$

Wages: The main dependent variable is the logarithm of the real hourly wage for West Germans in the West German labor market, measured in Euro at the prices of the year 1991. As shown in Table 1, the real hourly wages of West Germans in the product markets that are not subject to the firm entry regulation of the GTCC are, on average, more than 1.5 Euro higher in large establishments with high worker influence than in smaller ones with weaker worker influence. In the product markets with the firm entry regulation the corresponding averages are higher, but comparable in size and show a similar pattern 56 In our main estimation sample these wages vary substantially across time and occupation-age cells, while there is considerable overlap of the wage distributions that are specific to the three segments of interest (see Table B.3 in Appendix B). These are two core prerequisites for separately identifying segment-specific immigration effects on native wages.

Immigration: East German individuals who migrate from East to West Germany after reunification are identified as those survey participants who grew up in the region of the former GDR, currently reside in West Germany, and have German citizenship. The data on the region of youth residence is based on the following survey question: "Where did you grow up, that is, where did you spend most of your youth?"57

When estimating the impact of the labor supply shock per occupation $j$ and age group $g$ at time $t$ in the West German labor market, we use a measure of the share of East German employees per occupation-age-time cell $j g t$ in West Germany : $m_{j g t}^{E}=\frac{E_{j g t}}{N_{j g t}}$, taking values

\footnotetext{
${ }^{54}$ If we drop the last restriction, we find similar OLS estimation results as reported in Section 6 . The IV estimation results involving the alternative instruments, then, however, suffer from noisy immigration rates and instrument values in some of these small cells.

${ }^{55}$ Further demographic and work-related variables are explained in Appendix B.

${ }^{56}$ In Appendix B, we briefly discuss the wage variation in our data. See Antonczyk, Fitzenberger and Sommerfeld, 2010, Card, Heining and Kline, 2013, and Dustmann et al., 2009, on the evolution of the West German wage structure.

${ }^{57}$ Possible answer categories are: " 1 ) in the area of Germany, that is a) in West Germany, b) in East Germany (former German Democratic Republic), c) in pre-WWII German territories in Eastern Europe (Ostgebiete); 2) outside the area of Germany, that is a) in a country in the European Union at the date of the survey, b) in a country in Eastern Europe, c) in another country".
} 
between zero and one. We denote as $E_{j g t}$ the number of medium-educated German employees who grew up in the East, belong to the occupation-age cell $j g$, and reside in West Germany at time $t$. The total number of medium-educated German employees in cell $j g$ in West Germany at time $t$ is $N_{j g t}$. Using the numerator $E_{j g t}$ directly as alternative explanatory variable, we can show that our main empirical results are not driven by changes of the denominator. Both measures, $m_{j g t}^{E}$ and $E_{j g t}$, are set to zero in the case of the survey wave of 1986, as it was carried out before German reunification.

For the identification of segment-specific immigration effects on native wages it is crucial that the share of East German employees in West Germany shows substantial variation across years and across occupation-age cells, along with a considerable overlap of the segment-specific patterns. In Table B.4 in Appendix B we find these pattern.

As immigration can be endogenous in equations explaining native wages, we use as an instrument the following measure of the pool of all East Germans who exert an exogenous push effect on the occupation-age-time cell $j g t$ in the West German labor market: $p_{j g t}^{E}=$ $\sum_{s=1}^{S} \omega_{s j} D_{s g t}$. The dummy variable $D_{s g t}$ equals one if a medium-educated employee $s$ in age-group $g$ and time period $t$ works either in East or West Germany, grew up in East Germany, and received a vocational training degree, typically as part of the education in the GDR, in one of the occupations that is relevant for occupation $j$. $D_{\text {sgt }}$ otherwise equals zero 58 Relevant for occupation $j$ are all vocational training degrees that are held by East Germans working in occupation $j$. Per occupation, these are, on average, degrees from 8 occupations. More than 90 percent of East German migrants in our main sample completed their vocational training in GDR times (see Section 4.2). The weighting variable, $\omega_{s j}$, reflects how relevant the human capital of employee $s$ is for working in occupation $j$. For employees who work in occupation $j$, the weight equals one. Employees in occupations $k \neq j$ are those who have added relevant human capital by working in an occupation $k$ that is also relevant to occupation $j$. For these, the weight is equal to the share of East German workers in occupation $j$ with a vocational training in occupation $k$. We test the sensitivity of our results by considering two alternative pool measures, one of

\footnotetext{
${ }^{58}$ The data set used for constructing the instrumental variable covers 5,214 East Germans in the survey waves 1992 and 1999. 12 percent of these East Germans reported living in West Germany.
} 
which involves no weighting 59

Product and labor market regulation: For distinguishing between product markets with and without the firm entry regulation in the GTCC, we use an occupation-level as well as an industry-level measure. Our main measure of product market regulation relies directly on the law enumerating all the occupations for which it regulates firm entry, and identifies the employees in these regulated occupations from highly disaggregated information on the occupation in which they work 60 In our main sample, the main indicator of the firm entry regulation equals one for 21 aggregated 3-digit occupation classes with the regulation, and zero for 27 occupation classes without it. As an individual worker's occupation may differ from the product market focus of the firm in which he or she works, we construct an alternative measure using data on the industry affiliation of employers and entrepreneurs. Applying that one, we find consistent empirical results 61

To separate the segment where workers' influence on the decision-making of firms is strong from the segment where workers' influence is weak, we use a dummy variable. It is coded one in the case of strong worker influence through works councils, that is for employees in establishments with 50 or more employees, and zero otherwise. We, hereby, build on the empirical evidence discussed in Section 3.2 (See also Addison et al., 1997, and Beckmann et al., 2010). Note, among others, that our empirical models all include direct controls for firm size-effects on wage outcomes (see also 3.2 , Sections 4.1 and 6).

\footnotetext{
${ }^{59}$ Firstly, we abstain from considering all relevant vocational training degrees, but focus exclusively on the one in occupation $j$ itself: $p_{j g t}^{E, 1}=\sum_{s=1}^{S} \omega_{s j} J_{s g t}$, where $J_{s g t}$ is equal to one for a medium-educated employee $s$ in age-group $g$ and time period $t$ who works in East or West Germany, grew up in East Germany and received a vocational training degree in occupation $j$ in the GDR, and zero otherwise. The second alternative measure is the unweighted variant of that measure: $p_{j g t}^{E, 2}=\sum_{s=1}^{S} J_{s g t}$.

${ }^{60}$ Our main occupational data follows the 3-digit classification of occupational titles of the Federal Employment Bureau (Bundesagentur für Arbeit, BA) in the version of 1988 with 334 occupational classes. To separate between product markets with and without firm entry regulation we, however, also use data that is available at the level of the 1,990 4-digit classes in the 1988 classification.

${ }^{61}$ See Appendix $\mathrm{B}$ for measurement details and Section 6.3 for empirical results.
} 


\section{Empirical Results}

\subsection{Baseline Results}

To prepare the ground for investigating the variation of native wage responses to a major labor supply shock, depending on product and labor market regulation, we start by estimating the average response. The shock is the large, unanticipated wave of East Germans migrating to West Germany after the unique historical event of German reunification. We use the basic empirical model in equation 2 to estimate the average effect of the influx of East Germans on the wages of natives in the West German labor market.

In Table 2, we report OLS and IV estimates for the main sample of 17,776 observations on employees who grew up in West Germany, reside in West Germany, and have German citizenship. In all specifications, the dependent variable is the logarithm of the real hourly wage of native West German employees $\left(w_{i j g t}^{W}\right)$. The main explanatory variable is the share of East German employees in West Germany $\left(m_{j g t}^{E}\right)$. In addition, we always include occupation-age interactions to capture different permanent wage levels across occupationage cells. Occupation-time interactions and age-time interactions are included to pick up wage changes specific to occupations and age groups, respectively. Standard errors are robust and clustered at the occupation-age level to allow for unrestricted correlation between observations in the same occupation-age cell, and we weight observations to take into account the sampling design of the data (see also Appendix B).

The OLS estimates in Column 1 of Table 2 indicate no significant correlation between the logarithm of West Germans' real hourly wages and the share of East Germans in the West German labor market. Column 2 shows that the estimate remains insignificant if we add more explanatory variables to control directly for further sources of heterogeneity in wages. We include a gender dummy and quadratic polynomials in employee age and tenure to capture gender-, age-, and tenure-specific differences in wage levels ${ }^{62}$ We also add interactions between the survey time and the 2-digit industry of the establishment to capture wage changes due to demand shocks or collective bargaining outcomes that are

\footnotetext{
${ }^{62}$ The gender-, age-, and tenure-specific patterns in our wage data fit with those typically reported in the literature (Borjas, 2012).
} 
specific to certain industry-years.

Our main explanatory variable can, however, still be endogenous in that variant of the wage equation as immigrants and employers may anticipate occupation-age-specific wage changes over time that are not yet controlled for. We have thus introduced an instrumental variables approach in Section 4.2 . Our instrument for the share of East German employees in West Germany, $\mathrm{m}_{j g t}^{E}$, is the pool of all East German employees in West and East Germany who received a vocational training degree in GDR times in one of the occupations that is relevant for occupation $j$ (see also Sections 4.2 and 5). The instrument is denoted by $\mathrm{p}_{j g t}^{E}$. We apply two-stage least square estimation and show the first stage IV estimates in Panel B of Column 3 in Table 2. These estimates indicate a positive and strongly significant partial correlation of the excluded instrument with the share of East German employees in West Germany. The test statistic takes a value of 23.38 in the F-test on the irrelevance of the excluded instrument, implying rejection of the null hypothesis. In addition, we can reject the null hypothesis of the 2SLS bias exceeding 10 percent of the OLS bias in the weak identification test 63 The second stage IV estimate in Panel A in Column 3 is insignificant.

\subsection{Main Results}

We now turn to our main focus in this paper and investigate the impact of interacting product and labor market regulation on the response of wages to a labor supply shock. As discussed in section 2, we expect interacting regulation to weaken the otherwise negative response of native workers' wages to the immigration of workers who are closer substitutes in production than common immigrants.

In Column 1 of Table 3, we report OLS estimates of our main empirical model in equation 1 for the main sample. The dependent variable is, as above, the logarithm of the real hourly wage of native West German employees, $w_{i j g t}^{W}$. To allow for immigration affecting native wages differently across segments, we use three interaction terms as our main explanatory variables: the interaction of the share of East German employees in West

\footnotetext{
${ }^{63}$ See the Kleibergen-Paap Wald statistic at the bottom of Panel A of Column 3. See also Kleibergen and Paap, 2006, and Stock and Yogo, 2005.
} 
Germany, $m_{j g t}^{E}$, with the indicator for the competitive segment $C_{j g t}$ (i.e. almost free firm entry and weak worker influence on firm decision-making), the corresponding interaction with the indicator for the segment with both regulations, $B_{j g t}$, and the one for the intermediate segment, $I_{j g t}$. Arbitrary wage differences across segments are captured by directly including two of the three segment indicators, $C_{j g t}$ and $I_{j g t}$, and we allow for segmentspecific effects of the vector of employee characteristics, $X_{i j g t}{ }^{64}$ As above, we include full sets of occupation-age interactions, age-time interactions, occupation-time interactions and industry-time interactions and show robust standard errors that are clustered at the occupation-age level. ${ }^{65}$

The OLS estimate on the interaction between $C_{j g t}$ and $m_{j g t}^{E}$ is statistically significantly negative. The coefficient estimates on the two other segment-specific share terms are not statistically significantly different from zero. More importantly than that, the coefficient on the share term specific to the segment $B_{j g t}$ differs statistically significantly from the one specific to $C_{j g t} 66$

In Column 2 of Table 3 , we present the corresponding second stage IV estimates to address the concern that our main explanatory variables might be endogenous in the estimated wage equation ${ }^{67}$ Column 3 provides the results for our preferred model specification where we modify the set of excluded instruments. We extend it by constructing instrument terms that are specific to the two distinct worker groups in the intermediate segment $I_{j g t}$. These groups are characterized by either lacking product market regulation $\left(I .1_{j g t}\right)$ or weak labor market institutions $\left(I .2_{j g t}\right)$. The value of the Hansen J statistic testing for over-identifying restrictions indicates no rejection of the exclusion restrictions in this specification (see the bottom of Column 3 in Table 3). In Columns 4 and 5, we also report the OLS and second stage IV estimates of the model variant where we distinguish between

\footnotetext{
${ }^{64}$ This involves interacting each of the five variables in $X_{i j g t}$ with $C_{j g t}, B_{j g t}$ and $I_{j g t}$, respectively, and including the three resulting sets of interactions as additional explanatory variables. See also Section 4.2 .

${ }^{65}$ The results in Table 3 are robust to using the number of East Germans $E_{j g t}$ instead of $m_{j g t}^{E}$ as main explanatory variable, to eliminating individual characteristics as explanatory variables, and to adding group-specific age-gender and tenure-gender interactions (see Appendix Cand Rows 1 to 6 in Table C.1.

${ }^{66}$ See the p-value for the F-test on the null hypothesis $\beta^{B}=\beta^{C}$ at the end of Column 1.

${ }^{67}$ We use three first-stage equations, one for each of the three segment-specific share terms in the second stage equation, and three excluded instruments, one for each of the three segments and apply 2SLS.
} 
the two intermediate worker groups in both stages of the estimation 68 In addition, we find qualitatively similar results as those shown in Column 3 if we re-estimate the model specification using one of our alternative instruments 69

Table 4 shows the first stage IV estimates for the preferred model of Column 3 in Table 3. As expected, we find a positive partial correlation between each instrument specific to one of the polar segments, $C_{j g t}$ or $B_{j g t}$, and the interaction of the respective segment indicator with the share of East German employees in West Germany. The two instruments that correspond to the two worker groups in the intermediate segment are both positively correlated with the share terms specific to that segment. All other partial correlations of excluded instruments with share terms are insignificant. The test statistics take values between 24.7 and 17.2 in the corresponding F-tests on the irrelevance of the excluded instruments, implying rejection of the null hypotheses (see the bottom of Table 44) 70 The IV estimates in Table 3 indicate a negative effect of the influx of East German immigrants on the wages of native West Germans in the competitive segment $C_{j g t}$. This empirical finding is in line with our expectation of Section 2.2. Workers in that segment are in product markets with almost free firm entry and in establishments with weak worker influence on firm decision-making. This fits well with standard immigration models where product and labor markets are assumed to be perfectly competitive. In this setting, real wages are expected to reflect the marginal product of labor and a sudden increase in the labor supply due to immigrants who qualify as close substitutes in production exerts downward pressure on native wages.

The coefficient estimates on the interaction between the indicator for the intermediate segment $I_{j g t}$ and $m_{j g t}^{E}$ are also negative, but not statistically significantly so. We expected

\footnotetext{
${ }^{68}$ In the second stage equation, we include four share terms specific to the groups $C_{j g t}, I .1_{j g t}, I .2_{j g t}$, and $B_{j g t}$, the dummies indicating the groups $C_{j g t}$ and $B_{j g t}$ (note that more are not required due to the exhaustive set of occupation-age interactions that we include), four group-specific sets of employee characteristics, and all other explanatory variables as in equation 1. There are four first-stage equations, one for each of the four group-specific share terms and we use the disaggregated set of four excluded instruments already explained in the main text. The coefficient estimates on the share terms specific to $I .1_{j g t}$ and $I .2_{j g t}$ are not statistically different from each other which fits with our expectations outlined in Section 2.2 .

${ }^{69}$ See Section 5 for the description of the instruments and Appendix $\mathrm{C}$, as well as Rows 7 and 8 in Table C.1, for results.

${ }^{70}$ We can also reject the null hypothesis of the 2SLS bias exceeding 10 percent of the OLS bias in the weak identification test (see the Kleibergen-Paap Wald statistic at the bottom of Column 3 in Table 3 .
} 
a negative effect, and possibly a weak one, as wage setting in $I_{j g t}$ is influenced by either high competition in the product market or in the labor market, but not by both.

We find no effect in the segment $B_{j g t}$ which is opposite to $C_{j g t}$ in the sense that firm entry restrictions in product markets and worker-empowering labor market institutions exist simultaneously and are strong in $B_{j g t}$. The coefficient estimates on the share terms specific to the polar segment $B_{j g t}$ are statistically different from the ones specific to $C_{j g t}$ (see the F-test results at the bottom of Table 3). In Section 2.2, we argued that product market conditions allowing for persistent profits and labor market conditions implying strong worker influence on firm decision-making open up the opportunity for a wedge between real wages and the marginal product of labor. German works councils represent worker interests at the establishment level and do have the relevant information and rights to influence the firm decision-making at that disaggregated level. But their actual power depends on product market conditions. They can insulate incumbent native workers from negative wage effects in case of downward wage pressures only when product market conditions allow them to do so. Our empirical findings corroborate this hypothesis.

The size of the coefficient estimates in Column 3 of Table 3 indicate that a one percentage point increase in the share of East Germans causes a 1.57 percent decline in real hourly wages for native West German workers in the competitive segment of the West German labor market, but no decline for those in the segment with both regulations.71 These estimates suggest that the increase from zero to about four percentage points in the share of East Germans that hit the West German labor market unexpectedly during the 1990s reduced the wages of native West Germans in the competitive segment by about 6.26 percent. This is economically significant and reasonable, given that the wages of native West Germans in that segment increased by 19.22 percent between 1986 and 1999. Native wages in the segment with interacting product and labor market regulation were, in contrast, insulated from falling.

\footnotetext{
${ }^{71}$ Note that the point estimate of 1.5652 is in the ballpark of previous literature. Altonji and Card, 1991, for example, report a coefficient estimate (standard error) of -1.910 (0.706) for an IV-regression of the change in log weekly earnings of low-skilled black males on the change in the fraction of immigrants in U.S. cities and -1.369 (0.848) for low-skilled black women.
} 


\subsection{Robustness}

Identifying product market types and the strength of labor market institutions

To distinguish between regulated and unregulated product markets, we rely, so far, on a measure which is directly based on the German Trade and Crafts Code and on disaggregated occupational information (see Section 5). An individual worker's occupation does, however, not necessarily indicate the product market focus of the firm in which he or she works. ${ }^{72}$ To address this concern, we impose a stricter separation between product market types. We use an alternative industry-level measure to restrict our main estimation sample to the two following groups of employees: ${ }^{73}$ 1) employees in product markets with firm entry regulation, that is employees working in a regulated industry and a regulated occupation; 2) employees in an unregulated industry and an unregulated occupation. For that sub-sample of 14,061 employees, Columns 1 and 2 in Table 5 show similar coefficient estimates on the segment interactions with the share of East German employees in West Germany as we report for the main sample in Columns 1 and 3 of Table 3 .

To identify workers in establishments with weak and strong workers' influence on firm decision-making, we use establishment size information and a cut-off point of 50 employees ${ }^{74}$ The reliance on establishment size information might at first glance raise the concern that the observed heterogeneity in immigration effects on native wages across the segments could reflect a mechanism depending on establishment size that is independent of interacting product and labor market regulation. In particular, the employer size-wage premium literature argues that small establishments may operate, in general, under very different conditions and constraints than larger ones (see, for example, Brown and Medoff (1989), Idson and Oi (1999), and Oi and Idson (1999) 75 Moreover, wage dynamics within firms and across firms may differ and, accordingly, the composition of wage dynamics may vary across segments that are specific to different establishment size groups.

\footnotetext{
${ }^{72}$ Employees in an occupation not falling under the regulation may work for a firm that is primarily active in a regulated product market (i.e., a beautician may work at a hairdressers), and vice versa.

${ }^{73}$ For details on the measure, see Section 5 and Appendix $B$.

${ }^{74}$ See Section 3.2 and, for example, Addison et al., 1997, and Beckmann et al., 2010.

${ }^{75}$ Among the most prominent explanations for the wage premia that prevail in large firms after conditioning on observable characteristics are monitoring costs, efficiency wages, and managerial discretion.
} 
To see how relevant these issues are for our empirical findings, we start with restricting the size variation in our estimation sample by keeping only workers in medium-sized establishments around the cut-off point of 50 employees. The results in columns 3 and 4 of Table 5 indicate that our previous findings remain stable when re-estimating on the sub-sample covering only workers in medium-sized establishments with 10 to 499 employees. As shown in Rows 9 and 10 of Table C.1 in Appendix C, we again obtain consistent results if we reduce the sample even further ${ }^{76}$ In Rows 11 and 12, we report that the main empirical pattern is confirmed, even more pronounced if we exclude workers in establishments with between 50 and 99 employees from the main sample. This is in line with expectations as the share of establishments with works councils in the respective size class is at least 16.7 percentage points lower than in higher size classes, where the shares are between 84.4 and 100 percent (Addison et al., 1997).

As an influence of establishment size with the potential of invalidating our main claim needs to interact with the labor supply shock under consideration, we provide the following model extension. We directly model a general, size-dependent influence of immigration on native wages by adding establishment size and its interaction with the share of East Germans in West Germany as explanatory variables to the main model specifications of Columns 1 and 3 in Table 3.77 The OLS and IV estimates in Columns 1 and 2 of Table C.2 in Appendix C indicate a statistically significantly positive estimate for the size coefficient, in line with the view that there are general differences in wage changes in occupation-age cells over time across establishment size classes. The size-interacted share term, however, remains insignificant, providing no support for a general, size-dependent influence of immigration on native wages ${ }^{78}$ Most importantly, the results confirm a

\footnotetext{
${ }^{76}$ Note that these estimates on sub-samples without workers in large establishments also address the issue that large establishments are the most likely candidates for being active in many product markets, possibly partly markets covered by firm entry regulation, and partly not.

${ }^{77}$ Two facts are noteworthy here. Firstly, our main model specifications already partly capture sizerelated influences by controlling directly for the segment-specific indicators, and for segment-specific effects of employee characteristics. Secondly, our previous estimates do not show a statistically significantly negative response of native wages to the influx of East German immigrants for all workers in small establishments. We find such a response for the segment $C_{j g t}$ with workers in establishments with less than 50 employees in product markets with almost free firm entry, but not for the segment $I .2_{j g t}$ where workers are also in small establishments, but in regulated product markets (see Columns 4 and 5 of Table 3).

${ }^{78}$ Note that the findings are similar if we estimate a model with the two size-specific terms, but without
} 
negative impact of the influx of East Germans into the competitive segment $\mathrm{C}$, and that this negative impact differs from the impact for segment B. This is again in line with interacting product and labor market regulation being relevant.

Against the background of these findings, our distinction between labor market segments seems to capture the relevant product and labor market regulation. Our findings corroborate the view that works councils have the actual power to exert an influence on the wage response to changes in labor market conditions, such as a major, unexpected labor supply shock, when restrictions to firm entry into product markets allow them to do so.

\section{Work changes among native workers}

As explained in Section 4.1, the focus of our main empirical approach is on the changes of West Germans' wages in occupation-age cells over time that arise in response to the influx of East Germans into the respective occupation-age cells in the West German labor market during the same time period. While being appropriate in our context, the approach could be subject to the criticism that native West Germans may respond to the influx of East Germans by adapting their work, especially by changing their occupation, job or job tasks. If these responses differed across the segments that we compare, then, the differences in native wage responses that we observe across the segments could, at least in parts, reflect segment-specific changes in the composition of workers or in task assignment.

Occupational changes are not uncommon in Germany despite the high costs associated with them ${ }^{79}$ Therefore, we set out to test whether the segment-specific wage responses to immigration that we document could reflect segment-specific occupational change patterns among West Germans. Our survey data allow us to identify occupational changes and when these occurred 80 We can exclude observations involving an occupational change after 1988 from the sample and we re-estimate our preferred model specifications from Columns 1 and 3 of Table 3 on the restricted sample. As shown in Columns 1 and 2 of the segment-specific terms (see Columns 3 and 4 of Table C.2 in Appendix C).

${ }^{79}$ The costs are high as remuneration often rewards vocational training degrees and as the risk of being considered an unskilled or low-skilled worker is high in occupations in which one is not trained.

${ }^{80} \mathrm{We}$ make use of the following survey questions: 1 . "Since you finished school or your vocational training, have the tasks that you perform on the job changed to an extent that would lead you to speak of an occupational change?"; 2. "If you experienced such an occupational change, when was the last year this happened?". 
Table 6, the results corroborate our previous findings. We conclude that the differences in native wage responses to immigration that we observe across different segments are not driven by differential occupational mobility patterns of West Germans.

We also find confirmation for our view if we focus on the sub-sample of workers where the job tenure data indicates no job change after 1988 (see Rows 13 and 14 of Table C.1). Accordingly, our main findings cannot simply reflect segment-specific job mobility of West Germans, including job mobility to jobs in different establishment size classes or at alternative education levels.

Native West Germans may, in addition, respond to the influx of East Germans by specializing into different occupational tasks at the workplace, while not moving out of their initial occupation. Considering that option, we deviate from our main approach by allowing for imperfect substitutability between immigrants and natives within occupation-age cells. If natives move into highly remunerated tasks, this could mitigate negative consequences of immigration on natives' wages (see Peri (2012) and Peri and Sparber (2009), among others). Such task changes would be crucial in our context if they were more likely among natives in the segment with both regulations, $B_{j g t}$, than in other segments. Then, our finding of differential responses of natives' wages to immigration in different segments could reflect differential task specialization of natives and immigrants taking place, rather than the influence of interacting product and labor market regulation.

To investigate this possibility, we search for segment-specific shifts in West Germans' occupational task content towards more advanced tasks in response to the immigration of East Germans. Advanced tasks require detailed knowledge of the operating work environment, such as designing, making plans, and monitoring machines. West Germans should have a comparative advantage over East Germans in these tasks because occupational skill acquisition in East and West Germany before reunification had not only many common features, but differed with respect to on-the-job skill acquisition. That difference is a result of the distinct economic systems, contrasting business environments and differential technology adoption in the two regions.

We estimate equations explaining the extent to which West Germans perform advanced tasks on the job. As main explanatory variables, we use, as above, our immigration 
measure interacted with the indicators for the three segments. The results in Columns 3 and 4 of Table 6 suggest that natives specialized into advanced tasks in response to immigration, but there is no indication of differences across the three segments. The F-test results at the bottom of the table reject effect heterogeneity in all specifications at any standard level of statistical significance.

Overall, we find no support for segment-specific variation in immigration-induced mobility of native workers across occupations as an alternative explanation for the differential wage effects that we observe across segments. Similarly, we find no such support in case of mobility across jobs or across occupational tasks on the job.

\section{Additional robustness tests}

In Appendix C, we provide details on additional robustness tests. Of high interest is the fact that we see our main empirical findings confirmed when re-estimating our main model specifications on sub-samples that are restricted to selected product market groups (see, for example, Rows 15 and 16 of Table C.1 in Appendix C). Our estimation results indicate, in particular, that the mechanism generating the heterogeneity in native wage reactions to immigration that we focus on is different from the mechanisms that can explain the recent findings of Dustmann and Glitz (2013) or Steinhardt (2011). All other robustness tests in Table C.1 in Appendix C have already been mentioned 81

\section{Conclusions}

In this paper, we contribute comprehensive micro data evidence that establishes the interaction of product and labor market regulation as an important source of systematic heterogeneity in wage reactions to a large, sudden and unanticipated labor supply shock. The economic shock under consideration is the large and sudden influx of Germans onto the labor market of the Federal Republic of Germany after the unexpected fall of the Berlin Wall in 1989. The East German migrants grew up in the former German Democratic Republic and are more similar to native West German workers than common immigrants.

\footnotetext{
${ }^{81}$ Note that our main findings are also stable if we re-estimate on the 76 samples that result if we change the included mix of product markets by sequentially excluding observations from individual occupations or industries.
} 
To investigate the role of the regulatory interaction, we isolate different segments of the labor market and compare immigration effects across the segments.

In the competitive segment of the West German labor market firm entry into product markets is almost free and worker influence on the decision-making of firms is weak. For this segment, we find a negative native wage response to the influx of similar migrants. This finding fits with the standard immigration model where product and labor markets are assumed to be perfectly competitive and where immigrant and native labor are treated as close substitutes in production. In the competitive equilibrium real wages are determined by the marginal product of labor and the equilibrium wage falls if newly arriving immigrants shift the labor supply curve outward. For the labor market segment where strong product and labor market regulation exist simultaneously, we observe instead that native wages are detached from immigration-induced wage pressure. Our empirical findings suggests that the immigration impact depends on interacting product and labor market regulation: strong worker influence on the decision-making of profit-making firms creates a wedge between real wages and the marginal product of employees in this labor market segment, disconnecting the variation of native wages from changes to the marginal product of labor.

Our analysis reveals that ignoring regulatory conditions - and, in particular, their interaction - can obscure the effects of economic shocks on labor market outcomes which one might otherwise observe. We find indication of the interplay between product and labor market regulation being crucial, and indeed more so than one type of regulation in isolation. The implications of this finding are manifold and extend beyond the immigration literature: recognizing solely labor market institutions when investigating the impact of regulation on labor market outcomes can miss an important part of the picture. 


\section{References}

Acemoglu, D., D. Autor and D. Lyle. 2004. "Women, War, and Wages: The Effect of Female Labor Supply on the Wage Structure at Midcentury." Journal of Political Economy 112(3): 497-551.

Addison, J., A. Bryson, P. Teixeira, A. Pahnke and L. Bellmann. 2013. "The Extent of Collective Bargaining and Workplace Representation: Transitions between States and their Determinants. A Comparative Analysis of Germany and Great Britain." Scottish Journal of Political Economy 60(2): 182-209.

Addison, J., C. Schnabel and J. Wagner. 1997. "On the Determinants of Mandatory Works Councils in Germany." Industrial Relations 36(4): 419-445.

Aghion, P., R. Burgess, S. J. Redding, and F. Zilibotti. 2006 and 2008. "The Unequal Effects of Liberalization: Evidence from Dismantling the License Raj in India." National Bureau of Economic Research Working Paper 12031 and American Economic Review, 98(4): 1397-1412.

Altonji, J and D. Card. 1991. "The Effects of Immigration on the Labor Market Outcomes of Less-skilled Natives." In Immigration, Trade and the Labor Market, edited by J. M. Abowd and R. B. Freeman, 201-234, Chicago: University of Chicago Press.

Angrist, J. and A. Kugler. 2003. "Protective or Counter-Productive? Labour Market Institutions and the Effect of Immigration on EU Natives." Economic Journal 113(488): F302-F331.

Antecol, H., P. Kuhn and S. Trejo. 2006. "Assimilation via Prices or Quantities? Sources of Immigrant Earnings Growth in Australia, Canada, and the United States." Journal of Human Resources 41(4): 821-840.

Antonczyk, D., B. Fitzenberger, and K. Sommerfeld. 2010. "Rising Wage Inequality, the Decline in Collective Bargaining, and the Gender Wage Gap." Labour Economics 17(5): 835-847.

Beckmann, M., S. Föhr and M. Kräkel. 2010. "Rent Seeking, Employment Security and Works Councils: Theory and Evidence for Germany"." Schmalenbach Business Review 62(1): $2-40$.

Bertrand, M. and F. Kramarz. 2002. "Does Entry Regulation Hinder Job Creation? Evidence from the French Retail Industry." Quarterly Journal of Economics 117(4): 1369-1413.

Betriebsverfassungsgesetz (BetrVG). 1972. Fassung vom 23.12.1988. Bundesgesetzblatt 1989: I 1-902.

Blanchard, O. and F. Giavazzi. 2003. "Macroeconomic Effects of the Regulation and Deregulation in Goods and Labor Markets." Quarterly Journal of Economics 118(3): 879-907.

Bodvarsson, Ö., H. Van den Berg and J. Lewer. 2008. "Measuring Immigration's Effects on Labor Demand: A Reexamination of the Mariel Boatlift." Labor Economics 15(4): 560-574.

Bonin, H. 2005. "Wage and Employment Effects of Immigration to Germany: Evidence from a Skill Group Approach." Institute for the Study of Labor (IZA), Bonn, IZA Discussion Paper 1875. 
Borjas, G. 1995. "The Economic Benefits from Immigration." Journal of Economic Perspectives 9(2): 3-22.

Borjas, G. 1999. "The Economic Analysis of Immigration." In Handbook of Labor Economics, edited by O. Ashenfelter and D. Card, Vol. 3A, Chap. 28, 1697-1760, Amsterdam: Elsevier.

Borjas, G. 2003. "The Labor Demand Curve is Downward Sloping: Reexamining the Impact of Immigration on the Labor Market." Quarterly Journal of Economics 118(4): $1335-1373$.

Borjas, G. 2012. Labor Economics. Sixth Edition. Boston, MA: Mc Graw Hill.

Boustan, L. 2009. "Competition in the Promised Land: Black Migration and the Racial Wage Convergence in the North, 1940-1970." Journal of Economic History 69(3): 756783.

Boustan, L., P. Fishback, and S. Kantor. 2010. "The Effects of Internal Migration on Local Labor Markets: American Cities during the Great Depression." Journal of Labor Economics 28(4): 719-746.

Boyer, C. 1990. "“Deutsche Handwerksordnung" oder "zügellose Gewerbefreiheit"." In Von Stalingrad zur Währungsreform: Zur Sozialgeschichte des Umbruchs in Deutschland, edited by M. Broszat, K.-D. Henke and H. Woller, 427-467, Oldenbourg: Oldenbourg Wissenschaftsverlag.

Brown, C. and J. Medoff. 1989. "The Employer Size-Wage Effect." Journal of Political Economy 97(5): 1027-1059.

Brück-Klingberg, A., C. Burkert, H. Seibert und R. Wapler. 2007. "Spätaussiedler mit höherer Bildung sind öfter arbeitslos." Institut für Arbeitsmarkt- und Berufsforschung, IAB Kurzbericht 8/2007.

Brücker, H. and E. Jahn. 2011. "Migration and Wage-Setting: Reassessing the Labor Market Effects of Migration." Scandinavian Journal of Economics 113(2): 286-317.

Burda, M. and J. Hunt. 2001. "From Reunification to Economic Integration: Productivity and the Labor Market in Eastern Germany." Brookings Papers of Economic Activity, 2001(2): 1-71.

Card, D. 1990. "The Impact of the Mariel Boatlift on the Miami Labor Market." Industrial and Labor Relations Review, 43(2): 245-257.

Card, D. 2001. "Immigrant Inflows, Native Outflows, and the Local Market Impacts of Higher Immigration." Journal of Labor Economics, 19(1): 22-64.

Card, D., J. Heining and P. Kline. 2013. "Workplace Heterogeneity and the Rise of German Wage Inequality." Quarterly Journal of Economics 128(3): 967-1015.

Carlin, W. and D. Soskice. 2009. "German Economic Performance: Disentangling the Role of Supply-side Reforms, Macroeconomic Policy and Coordinated Economy Institutions." Socio-Economic Review 7(1): 67-99.

Chari, A. V. 2011. "Identifying the Aggregate Productivity Effects of Entry and Size Restrictions: An Empirical Analysis of License Reform in India." American Economic Journal: Economic Policy 3(2): 66-96. 
D'Amuri, F., G. Ottaviano and G. Peri. 2010. "The Labor Market Impact of Immigration in Western Germany in the 1990s" European Economic Review 54 (4): 550-570.

Deregulierungskommission. 1991. "Marktöffnung und Wettbewerb - Deregulierung als Programm?" Gutachten der Unabhängigen Expertenkommission zum Abbau marktwidriger Regulierungen, Stuttgart: Poeschel.

DiNardo, J. and J.-S. Pischke. 1997. "The Returns to Computer Use Revisited: Have Pencils Changed the Wage Structure Too?" Quarterly Journal of Economics 112(1): 291-303.

Djankov, S., R. La Porta, F. Lopez-De-Silanes and A. Shleifer, A. 2002. "The Regulation of Entry." Quarterly Journal of Economics 117(1): 1-37.

Dustmann, C., J. Ludsteck and U. Schönberg. 2009. "Revisiting the German Wage Structure." Quarterly Journal of Economics 124(2): 843-881.

Dustmann, C. and A. Glitz. 2013. "How do Industries and Firms Respond to Changes in Local Labor Supply?" University College London and Universitat Pompeu Fabra, mimeo.

Ebell, M. and C. Haefke. 2006. "Product Market Regulation and Endogenous Union Formation." Institute for the Study of Labor, IZA Discussion Paper 2222.

Entorf, H. and F. Kramarz. 1997. "Does Unmeasured Ability Explain the Higher Wages of New Technology Workers?" European Economic Review 41(8): 1489-1509.

Fiori, G., G. Nicoletti, S. Scarpetta and F. Schiantarelli, 2012. "Employment Effects of Product and Labour Market Reforms: Are There Synergies?" Economic Journal 122(558): F79-F104.

Fitzenberger, B., K. Kohn and Q. Wang. 2011. "The Erosion of Union Membership in Germany: Determinants, Densities, Decompositions." Journal of Population Economics 24(1): 141-165.

Frank, D. 2009. "The Effect of Migration on Natives' Employment Outcomes: Evidence from the Fall of the Berlin Wall." INSEAD Working Paper 2009/54/ST, INSEAD, Fontainbleau.

Friedberg, R. 2001. "The Impact of Mass Migration on the Israeli Labor Market." Quarterly Journal of Economics 116(4): 1373-1408.

Fuchs-Schündeln, N. and R. Izem. 2012. "Explaining the Low Labor Productivity in East Germany - A Spatial Analysis." Journal of Comparative Economics 40(1): 1-21.

Fuchs-Schündeln, N. and M. Schündeln. 2009. "Who Stays, Who Goes, Who Returns? East-West Migration within Germany since Reunification." Economics of Transition 17(4): 703-738.

Gathmann, C. and U. Schönberg. 2010. "How General is Human Capital? A Task-Based Approach." Journal of Labor Economics 28(1): 1-49.

Gersbach, H. and G. Sheldon. 1996. "Structural Reforms and their Implications for Macroeconomic Policies." In Macroeconomic Policies and Structural Reforms, 131-167, OECD Proceedings, Paris: Organisation for Economic Co-operation and Development (OECD).

Gesetz zur Ordnung des Handwerks (Handwerksordnung, HWO). 1953. Fassung vom 28.12.1965. Bundesgesetzesblatt 1966: I,1 1-33. 
Glitz, A. 2012. "The Labor Market Impact of Immigration: A Quasi-Experiment Exploiting Immigrant Location Rules in Germany." Journal of Labor Economics 30(1): 175-213.

Griffith, R., R. Harrison and G. Macartney. 2007. "Product Market Reforms, Labor Market Institutions and Unemployment." Economic Journal 117(519): C142-C166.

Hanson, G. H. and M. Slaughter. 2002. "Labor-Market Adjustment in Open Economies: Evidence from US States." Journal of International Economics 57(1): 3-29.

Harhoff, D. and T. Kane. 1997. "Is the German Apprenticeship System a Panacea for the U.S. Labor Market?" Journal of Population Economics 10(2): 171-196.

Hassel, A. 1999. "The Erosion of the German System of Industrial Relations." British Journal of Industrial Relations 37(3): 483-505.

Hassel, A. and B. Rehder. 2001. "Institutional Change in the German Wage Bargaining System - The Role of Big Companies." Max Planck Institute for the Study of Societies, Working Paper 01/9.

Hunt, J. 2006. "Staunching Emigration from East Germany: Age and the Determinants of Migration." Journal of the European Economic Association 4(5): 1014-1037.

Idson, T. L. and W. Y. Oi. 1999. "Workers Are More Productive in Large Firms." American Economic Review 89(2): 104-108.

Jaeger, D. 2007. "Skill Differences and the Effect of Immigrants on the Wages of Natives." Mimeo, College of William and Mary, Williamsburg.

Kahn, L. 2004. "Immigration, Skills and the Labor Market: International Evidence." Journal of Population Economics 17(3): 501-534.

Kambourov, G. and I. Manovskii. 2009. "Occupational Specificity of Human Capital." International Economic Review 50(1): 63-115.

Kleibergen, F. and R. Paap. 2006. "Generalized Reduced Rank Tests Using the Singular Value Decomposition." Journal of Econometrics 133(1): 97-126.

Kleiner, M. 2000. "Occupational Licensing." Journal of Economic Perspectives 14(4): 189-202.

Koeniger, W. and J. Prat, 2007, "Employment Protection, Product Market Regulation and Firm Selection." Economic Journal 117(521): F302-F332.

Kugler, A., and G. Pica, 2006. "The Effects of Employment Protection and Product Market Regulations on the Italian Labor Market." In: Labour Market Adjustments in Europe., edited by J. Messina, C. Michelacci, J. Turunen, G. Zoega, Cheltenham, U.K.: Edward Elgar.

Krueger, A. and J.-S. Pischke. 1995. "A Comparative Analysis of East and West German Labor Markets: Before and After Unification." In Differences and Changes in Wage Structures, edited by R. Freemann and L. Katz, 405-446, NBER Comparative Labor Market Series, Chicago: University of Chicago Press.

Krueger, A. and J.-S. Pischke. 1998. "Observations and Conjectures on the U.S. Employment Miracle." In Third Public GAAC Symposium: Labor Markets in the USA and Germany, 99-126, Bonn: German-American Academic Council. 
Lewis, E. 2004. "How did the Miami Labor Market absorb the Mariel Immigrants?" Working Paper No. 04-3, Federal Reserve Bank of Philadelphia.

Lewis, E. 2011. "Immigration, Skill Mix, and Capital-Skill Complementarity.", Quarterly Journal of Economics 126(2): 1029-1069.

Lewis, E. 2013. "Immigrant-Native Substitutability and the Role of Language." In Immigration, Poverty and Socioeconomic Inequality, edited by D. Card and S. Raphael, 60-97, New York: Russell Sage Foundation.

Manacorda, M., A. Manning, and J. Wadsworth. 2012. "The Impact Of Immigration On The Structure Of Wages: Theory And Evidence From Britain." Journal of the European Economic Association 10(1): 120-151.

Monopolkommission. 1998. "Marktöffnung umfassend verwirklichen." 12. Hauptgutachten der Monopolkommission 1996/97, Baden-Baden, Germany: Nomos.

Monopolkommission. 2002. "Reform der Handwerksordnung." 31. Sondergutachten der Monopolkommission, Baden-Baden, Germany: Nomos.

Oi, W. Y. and T. L. Idson. 1999. "Firm Size and Wages." In Handbook of Labor Economics, edited by O. Ashenfelter and D. Card, Vol. 3, Part B (Chapter 33), 21652214, Amsterdam: North-Holland.

Ottaviano, G. and G. Peri. 2012. "Rethinking the Effects of Immigration on Wages." Journal of the European Economic Association 10(1): 152-197.

Peri, G. 2012. "The Effect of Immigration on Productivity: Evidence from U.S. States." Review of Economics and Statistics 94(1): 348-358.

Peri, G. and G. Sparber. 2009. "Task Specialization, Immigration, and Wages." American Economic Journal: Applied Economics 1(3): 135-169.

Prantl, S. and A. Spitz-Oener. 2009. "How does Entry Regulation Influence Entry into Self-employment and Occupational Mobility?" Economics of Transition 17(4): 769-802.

Seldeslachts, J. 2008. "Synchronising Deregulation in Product and Labor Markets." Scottish Journal of Political Economy 55(5): 591-617.

Spector, D. 2004. "Competition and the Capital-Labor Conflict." European Economic Review 48(1): 25-38.

Spitz-Oener, A. 2006. "Technical Change, Job Tasks, and Rising Educational Demands: Looking outside the Wage Structure." Journal of Labor Economics 24(2): 235-270.

Steinhardt, M. 2011. "The Wage Impact of Immigration in Germany - New Evidence for Skill Groups and Occupations." The B.E. Journal of Economic Analysis and Policy 11(1) (Contributions): Article 31.

Stock, J. and M. Yogo. 2005. "Testing for Weak Instruments in Linear IV Regressions." In Identification and Inference for Econometric Models, edited by D. Andrews and J. Stock, 80-108, Cambridge, MA: Cambridge University Press.

Tirole, J. 1988. The Theory of Industrial Organization. Cambridge, MA: MIT Press.

Welch, F. 1979. "Effects of Cohort Size on Earnings: The Baby Boom Babies' Financial Bust." Journal of Political Economy, 87(5,2): S65-S97. 


\section{Figures and Tables}

Figure 1: Migration between East and West Germany, 1985-1999

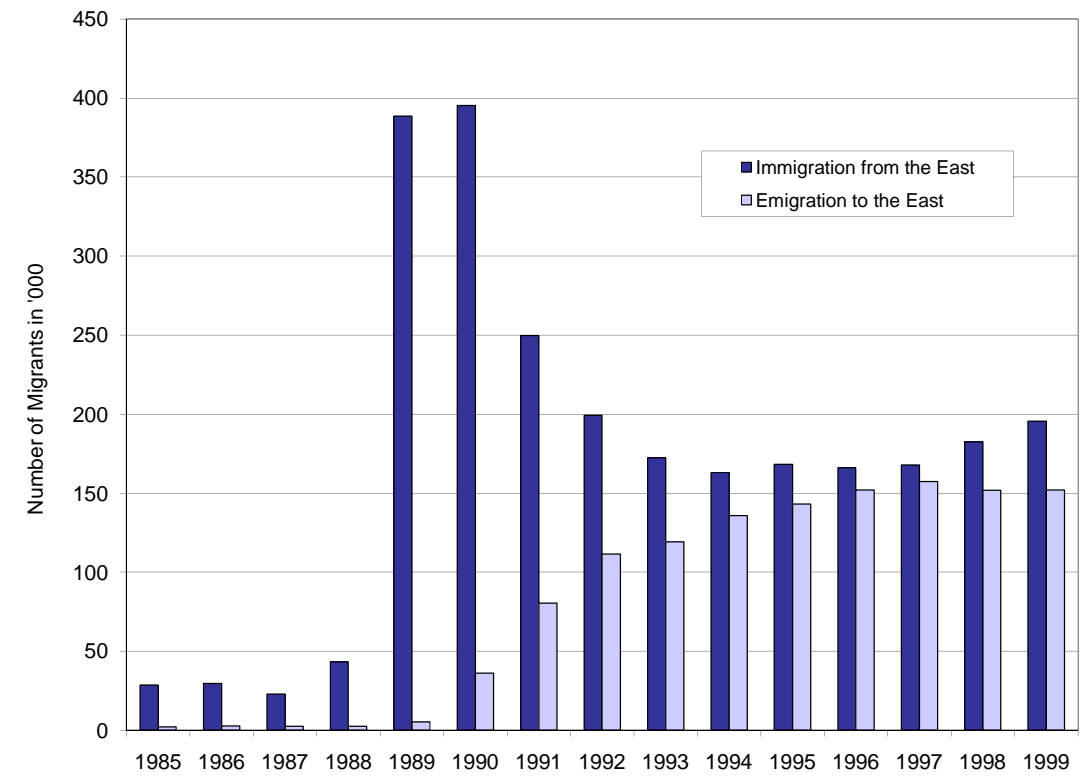

In this figure, we show the pattern of migration between East and West Germany for the time period between 1985 and 1999.

Data source: Federal Statistical Office of Germany. 
Table 1: Mean real hourly wages of Germans in West Germany

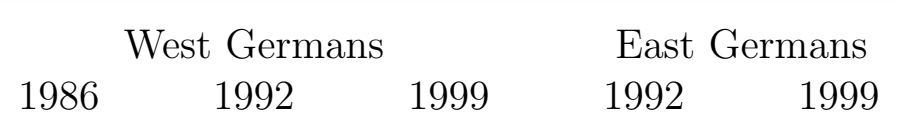

Employees in product markets

without GTCC entry regulation and establishments...

$\begin{array}{lccccc}\text { with weak worker influence } & 7.75 & 8.72 & 9.24 & 8.16 & 7.57 \\ (<50 \text { employees }) & (4.04) & (4.18) & (6.82) & (3.63) & (2.62) \\ \text { with strong worker influence } & 9.29 & 10.61 & 11.37 & 10.06 & 10.94 \\ \begin{array}{l}(\geq 50 \text { employees }) \\ (4.45)\end{array} & (3.58) & (7.01) & (3.45) & (4.82)\end{array}$

Employees in product markets

with GTCC entry regulation and establishments...

$\begin{array}{lccccc}\text { with weak worker influence } & 8.37 & 9.36 & 9.43 & 9.12 & 9.44 \\ \text { (<50 employees) } & (2.97) & (2.74) & (3.40) & (2.87) & (4.12) \\ \text { with strong worker influence } & 9.25 & 10.69 & 11.57 & 9.73 & 10.58 \\ \text { ( } \geq 50 \text { employees) } & (2.80) & (2.78) & (3.78) & (2.76) & (3.42)\end{array}$

Notes: In this table, we provide means of real hourly wages of West and East Germans in West Germany in 1991 Euro with standard deviations in brackets. We provide means per survey wave for four employee groups that differ with respect to product and labor market regulation. The calculations are based on a sample of 18,928 employees who participated in the survey waves 1986, 1992 or 1999, grew up in East or West Germany, reside in West Germany, have German citizenship, work between 10 and 75 hours per week, are between 25 and 54 years old, have a medium level of education, and report all data relevant to our study. Excluded are employees in the public sector, in non-profit organizations or the mining and quarrying sector, and in occupations that are not accredited by the BMBF and the BIBB. 
Table 2: The average impact of East German immigrants on

West Germans' wages

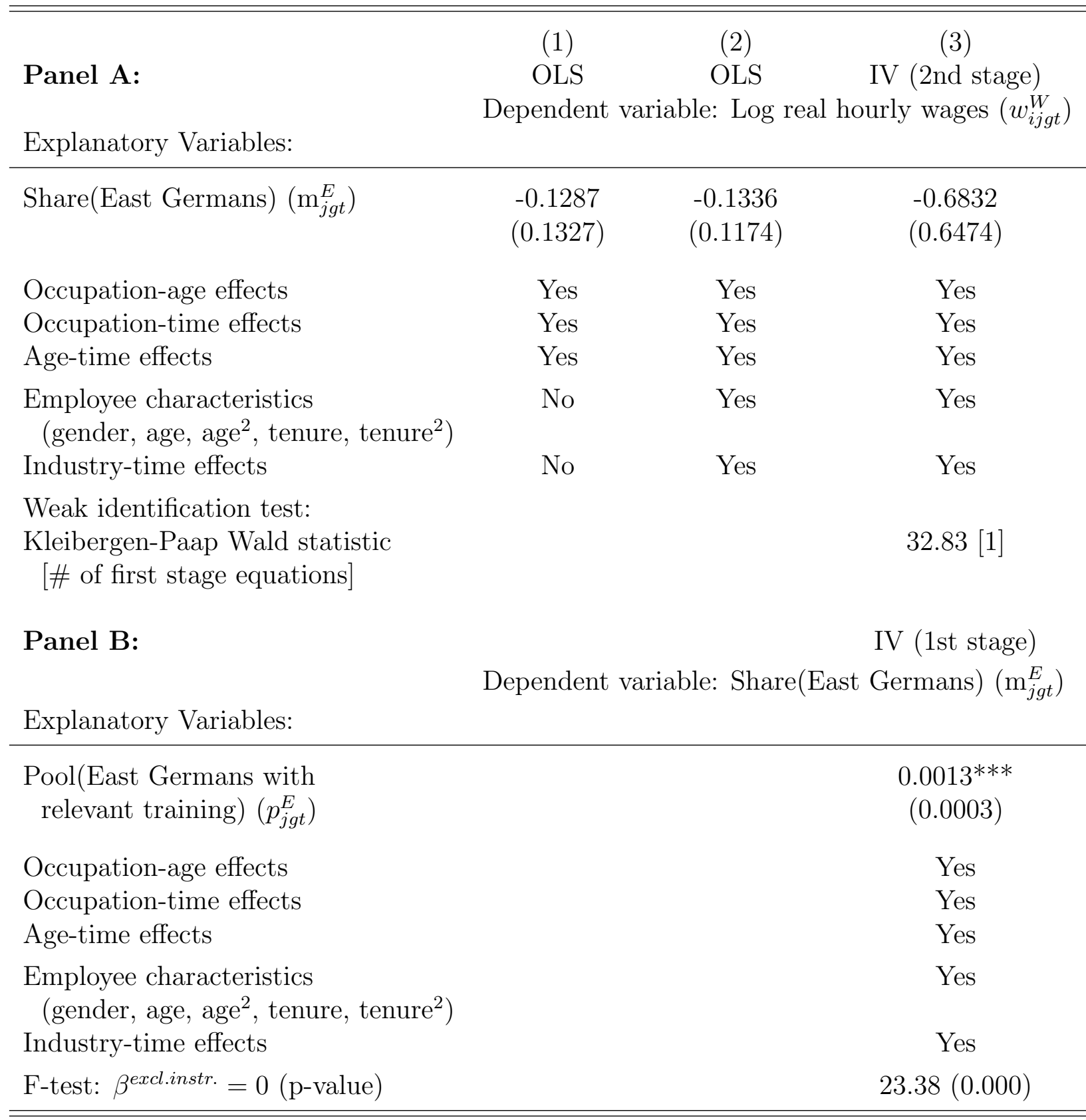

Notes: In this table, we show OLS and IV estimates of wage equations for the main sample of 17,776 employees in the survey waves 1986, 1992 or 1999. All sampled employees grew up in West Germany, reside in West Germany, have German citizenship, work between 10 and 75 hours per week, are between 25 and 54 years old, have a medium level of education, and report all the data relevant here. Excluded are employees in the public sector, non-profit organizations, the mining and quarrying sector, occupations not accredited by the BMBF/BIBB, and occupation-age-time cells with less than 5 employees fulfilling the previous conditions (see also Section 5 and Appendix B). Observations are weighted to take account of the sampling design. Robust standard errors in parentheses are clustered to allow for unrestricted correlation between observations in the same occupation-age cell. Statistical significance at the $1 \%$ (5\%, $10 \%$ ) level is indicated by $* * *(* *, *)$. 
Table 3: The impact of East German immigrants on West Germans' wages by segment of the West German labor market

\begin{tabular}{|c|c|c|c|c|c|}
\hline Explanatory variables: & $\begin{array}{c}(1) \\
\text { OLS } \\
\text { Dependent }\end{array}$ & $\begin{array}{c}(2) \\
\text { IV } \\
\text { ariable: Lo }\end{array}$ & $\begin{array}{l}\text { (3) } \\
\text { IV } \\
\text { g real hour }\end{array}$ & $\begin{array}{l}\text { OLS } \\
\text { y wages }\left(w_{i j s}^{W}\right.\end{array}$ & $\begin{array}{l}(5) \\
\text { IV }\end{array}$ \\
\hline $\begin{array}{l}\text { Competitive segment }\left(C_{j g t}\right) * \\
\quad \text { Share(East Germans })\left(\mathrm{m}_{j g t}^{E}\right)\end{array}$ & $\begin{array}{c}-0.6747^{* * *} \\
(0.2275)\end{array}$ & $\begin{array}{c}-1.5436^{* *} \\
(0.6742)\end{array}$ & $\begin{array}{c}-1.5652^{* *} \\
(0.6755)\end{array}$ & $\begin{array}{c}-0.6337^{* * *} \\
(0.2307)\end{array}$ & $\begin{array}{c}-1.8561^{* *} \\
(0.8493)\end{array}$ \\
\hline $\begin{array}{l}\text { Intermediate segment }\left(I_{j g t}\right) * \\
\quad m_{j g t}^{E}\end{array}$ & $\begin{array}{l}-0.0921 \\
(0.1466)\end{array}$ & $\begin{array}{l}-0.5151 \\
(0.7347)\end{array}$ & $\begin{array}{l}-0.5269 \\
(0.7447)\end{array}$ & & \\
\hline $\begin{array}{l}I .1_{j g t} * m_{j g t}^{E}(\text { No GTCC entry } \\
\quad \text { regulation } * \text { Strong worker influence }) \\
I .2_{j g t} * m_{j g t}^{E}(\text { GTCC entry } \\
\quad \text { regulation } * \text { Weak worker influence })\end{array}$ & & & & $\begin{array}{l}-0.0006 \\
(0.2156) \\
-0.1768 \\
(0.1980)\end{array}$ & $\begin{array}{c}-0.8921 \\
(1.1890) \\
0.0796 \\
(0.8738)\end{array}$ \\
\hline $\begin{array}{l}\text { Segment with both } \\
\quad \text { regulations }\left(B_{j g t}\right) * m_{j g t}^{E}\end{array}$ & $\begin{array}{c}0.2752 \\
(0.2159)\end{array}$ & $\begin{array}{c}0.6980 \\
(0.8189)\end{array}$ & $\begin{array}{c}0.7043 \\
(0.8164)\end{array}$ & $\begin{array}{c}0.2476 \\
(0.2141)\end{array}$ & $\begin{array}{c}1.1131 \\
(0.9266)\end{array}$ \\
\hline Indicator for segment $C_{j g t}$ & Yes & Yes & Yes & Yes & Yes \\
\hline $\begin{array}{l}\text { Indicator(s) for segment } I_{j g t} \\
\text { or groups } I .1_{j g t} \text { and } I .2_{j g t}\end{array}$ & Yes & Yes & Yes & Yes & Yes \\
\hline $\begin{array}{l}\text { Segment- or group-specific } \\
\text { individual characteristics }\end{array}$ & Yes & Yes & Yes & Yes & Yes \\
\hline Occupation-age effects & Yes & Yes & Yes & Yes & Yes \\
\hline Occupation-time effects & Yes & Yes & Yes & Yes & Yes \\
\hline Age-time effects & Yes & Yes & Yes & Yes & Yes \\
\hline Industry-time effects & Yes & Yes & Yes & Yes & Yes \\
\hline $\begin{array}{l}\text { F-test: } \beta^{I .1}=\beta^{I .2}(\mathrm{p} \text {-value }) \\
\text { F-test: } \beta^{C}=\beta^{I}(\mathrm{p} \text {-value }) \\
\text { F-test: } \beta^{B}=\beta^{I}(\mathrm{p} \text {-value }) \\
\left.\text { F-test: } \beta^{B}=\beta^{C} \text { (p-value }\right)\end{array}$ & $\begin{array}{l}0.0242 \\
0.1390 \\
0.0034\end{array}$ & $\begin{array}{l}0.1984 \\
0.0751 \\
0.0151\end{array}$ & $\begin{array}{l}0.1899 \\
0.0747 \\
0.0131\end{array}$ & 0.5474 & 0.5469 \\
\hline $\begin{array}{l}\text { Weak identification test: } \\
\text { Kleibergen-Paap Wald statistic } \\
{\left[\# 1^{s t} \text { stage equations }\right]}\end{array}$ & & $11.28[3]$ & $8.56[3]$ & & $4.29[4]$ \\
\hline Hansen J statistic (p-value) & & & 0.5269 & & \\
\hline
\end{tabular}

Notes: In this table, we show OLS and second stage IV estimates of wage equations for our main sample of 17,776 observations (see also Table 2, Section 5 and Appendix B). Segment/group-specific individual characteristics are gender, age, age ${ }^{2}$, tenure, and tenure ${ }^{2}$, all interacted with the dummies for the three/four different segments or worker groups considered in the respective OLS or second stage IV equation. The set of excluded instruments in column 2 consists of the interactions between the three segments $C_{j g t}, B_{j g t}, I_{j g t}$ and the pool of East German employees exerting a push effect. Our measure of the pool is the number of medium-educated employees who work in age-group $g$ in East or West Germany in time period $t$, who grew up in East Germany and who have a vocational training degree that is relevant for occupation $j$ and was typically part of their education in the GDR. In column 3 and 5 , the set of instruments consists of the four interactions of the pool measure with the worker groups $C_{j g t}, I .1_{j g t}, I .2_{j g t}$, and $B_{j g t}$. See Table 4 for first stage results corresponding to column 3. Observations are weighted to take account of the sampling design. Robust standard errors in parentheses are clustered to allow for unrestricted correlation between observations in the same occupation-age cell. Statistical significance at the $1 \%(5 \%, 10 \%)$ level is indicated by $* * *(* *, *)$. 
Table 4: First stage IV estimates fitting with the second stage estimates in column 3 of Table 3

Explanatory variables:

$\begin{array}{ccc}(1) & (2) & (3) \\ \operatorname{IV}(1 \mathrm{st}) & \operatorname{IV}(1 \mathrm{st}) & \operatorname{IV}(1 \mathrm{st}) \\ & \text { Dependent variables: } & \\ C_{j g t}{ }^{*} \text { Share(East } & \text { Intermediate } & B_{j g t}{ }^{*} \mathrm{~m}_{j g t}^{E} \\ \begin{array}{cc}\text { Germans }) \\ \left(\mathrm{m}_{j g t}^{E}\right)\end{array} & \text { segment } & \\ & \left(I_{j g t}\right) * \mathrm{~m}_{j g t}^{E} & \end{array}$

\section{Competitive segment $\left(C_{j g t}\right) *$} Pool(East Germans with relevant training) $\left(p_{j g t}^{E}\right)$

\section{$I .1_{j g t} * p_{j g t}^{E}$ (No GTCC entry regulation} $*$ Strong worker influence)

$I .2_{j g t} * p_{j g t}^{E}$ (GTCC entry regulation $*$ Weak worker influence)

Labor market segment with both regulations $\left(B_{j g t}\right) * p_{j g t}^{E}$

Indicator for segment $C_{j g t}$

Indicator for segment $I_{j g t}$

Segment-specific

individual characteristics

Occupation-age effects

Occupation-time effects

Age-time effects

Industry-time effects

F-test: $\beta^{\text {excl.instr. }}=0$ ( $\mathrm{p}$-value $)$

$\begin{array}{ccc}0.0011^{* * *} & 0.0002 & -0.00001 \\ (0.0002) & (0.0002) & (0.0001)\end{array}$

$\begin{array}{ccc}0.0002 & 0.0012^{* * *} & -0.00002 \\ (0.0002) & (0.0002) & (0.0001) \\ 0.0001 & 0.0012^{* * *} & 0.00004 \\ (0.0001) & (0.0003) & (0.0002)\end{array}$

0.0001

$(0.0001)$

0.0001

(0.0002)

$0.0013^{* * *}$

(0.0002)

Yes

Yes

Yes

Yes

Yes

Yes

Yes

Yes

Yes

$\begin{array}{ccc}\text { Yes } & \text { Yes } & \text { Yes } \\ \text { Yes } & \text { Yes } & \text { Yes } \\ \text { Yes } & \text { Yes } & \text { Yes } \\ \text { Yes } & \text { Yes } & \text { Yes } \\ 58(0.00) & 24.70(0.00) & 17.17(0.00)\end{array}$

Notes: In this table, we provide first stage IV estimates fitting with the second stage estimates in column 3 of Table 3 . We use the main sample of 17,776 observations (see also Table 2 Section 5 and Appendix B]. Segment-specific individual characteristics are gender, age, age $^{2}$, tenure, and tenure ${ }^{2}$, all interacted with the dummies for the three segments $C_{j g t}, I_{j g t}$, and $B_{j g t}$.

Observations are weighted to take account of the sampling design. Robust standard errors in parentheses are clustered to allow for unrestricted correlation between observations in the same occupation-age cell. Statistical significance at the $1 \%(5 \%, 10 \%)$ level is indicated by $* * *(* *, *)$. 
Table 5: Alternative model specifications, Part 1

\begin{tabular}{|c|c|c|c|c|}
\hline \multirow[b]{2}{*}{ Explanatory variables: } & $\begin{array}{l}(1) \\
\text { OLS }\end{array}$ & $\begin{array}{l}(2) \\
\text { IV }\end{array}$ & $\begin{array}{l}(3) \\
\text { OLS }\end{array}$ & $\begin{array}{l}(4) \\
\text { IV }\end{array}$ \\
\hline & \multicolumn{4}{|c|}{ Dependent variable: Log real hourly wages $\left(w_{i j g t}^{W}\right)$} \\
\hline $\begin{array}{l}\text { Competitive segment }\left(C_{j g t}\right) * \\
\quad \text { Share(East Germans) }\left(\mathrm{m}_{j g t}^{E}\right)\end{array}$ & $\begin{array}{c}-0.7867^{* * *} \\
(0.2778)\end{array}$ & $\begin{array}{c}-1.8190^{* *} \\
(0.7266)\end{array}$ & $\begin{array}{c}-0.7656^{* * *} \\
(0.2911)\end{array}$ & $\begin{array}{c}-1.5490 * * \\
(0.7666)\end{array}$ \\
\hline $\begin{array}{l}\text { Intermediate segment } \\
\qquad\left(I_{j g t}\right) * m_{j g t}^{E}\end{array}$ & $\begin{array}{l}-0.0159 \\
(0.1659)\end{array}$ & $\begin{array}{l}-0.8662 \\
(0.8851)\end{array}$ & $\begin{array}{l}-0.1468 \\
(0.1901)\end{array}$ & $\begin{array}{l}-0.3991 \\
(0.8825)\end{array}$ \\
\hline $\begin{array}{l}\text { Segment with both } \\
\quad \text { regulations }\left(B_{j g t}\right) * m_{j g t}^{E}\end{array}$ & $\begin{array}{c}0.2293 \\
(0.2563)\end{array}$ & $\begin{array}{c}0.4139 \\
(0.9505)\end{array}$ & $\begin{array}{c}0.4683 \\
(0.2582)\end{array}$ & $\begin{array}{c}1.2021 \\
(1.0116)\end{array}$ \\
\hline Indicator for segment $C_{j g t}$ & Yes & Yes & Yes & Yes \\
\hline Indicator for segment $I_{j g t}$ & Yes & Yes & Yes & Yes \\
\hline $\begin{array}{l}\text { Segment-specific } \\
\text { individual characteristics }\end{array}$ & Yes & Yes & Yes & Yes \\
\hline Occupation-age effects & Yes & Yes & Yes & Yes \\
\hline Occupation-time effects & Yes & Yes & Yes & Yes \\
\hline Age-time effects & Yes & Yes & Yes & Yes \\
\hline Industry-time effects & Yes & Yes & Yes & Yes \\
\hline F-test: $\beta^{C}=\beta^{I}(\mathrm{p}$-value $)$ & 0.0147 & 0.3025 & 0.0662 & 0.2159 \\
\hline F-test: $\beta^{B}=\beta^{I}$ (p-value $)$ & 0.3790 & 0.0848 & 0.0382 & 0.0470 \\
\hline F-test: $\beta^{B}=\beta^{C}$ (p-value $)$ & 0.0084 & 0.0330 & 0.0022 & 0.0137 \\
\hline $\begin{array}{l}\text { Weak identification test: } \\
\text { Kleibergen-Paap Wald statistic } \\
{\left[\# 1^{\text {st }} \text { stage equations }\right]}\end{array}$ & & $9.607[3]$ & & $6.950[3]$ \\
\hline Hansen J statistic (p-value) & & 0.2183 & & 0.7300 \\
\hline Observations & 14,061 & 14,061 & 10,201 & 10,201 \\
\hline
\end{tabular}

Notes: In columns 1 and 2, we provide OLS and IV estimates of wage equations for a sub-sample of 14,061 observations from the main sample described in Table 2, All included observations fulfill a stricter definition of product market types, belonging to one of the two following groups of employees: 1) employees in product markets with firm entry regulation who work in a regulated industry and a regulated occupation; 2) employees in an unregulated industry and an unregulated occupation. In columns 3 and 4, we use the sub-sample of 10,201 observations on workers in medium-sized establishments that have between 10 and 499 workers.

The set of excluded instruments in columns 2 and 4 consists of four interactions between the worker groups $C_{j g t}, I .1_{j g t}, I .2_{j g t}, B_{j g t}$ and the immigration pool measure. Segment-specific individual characteristics are gender, age, age ${ }^{2}$, tenure, and tenure ${ }^{2}$, all interacted with the dummies for the three segments $C_{j g t}, I_{j g t}$, and $B_{j g t}$.

Observations are weighted to take account of the sampling design. Robust standard errors in parentheses are clustered to allow for unrestricted correlation between observations in the same occupation-age cell. Statistical significance at the $1 \%(5 \%, 10 \%)$ level is indicated by $* * *(* *, *)$. 
Table 6: Alternative model specifications, Part 2

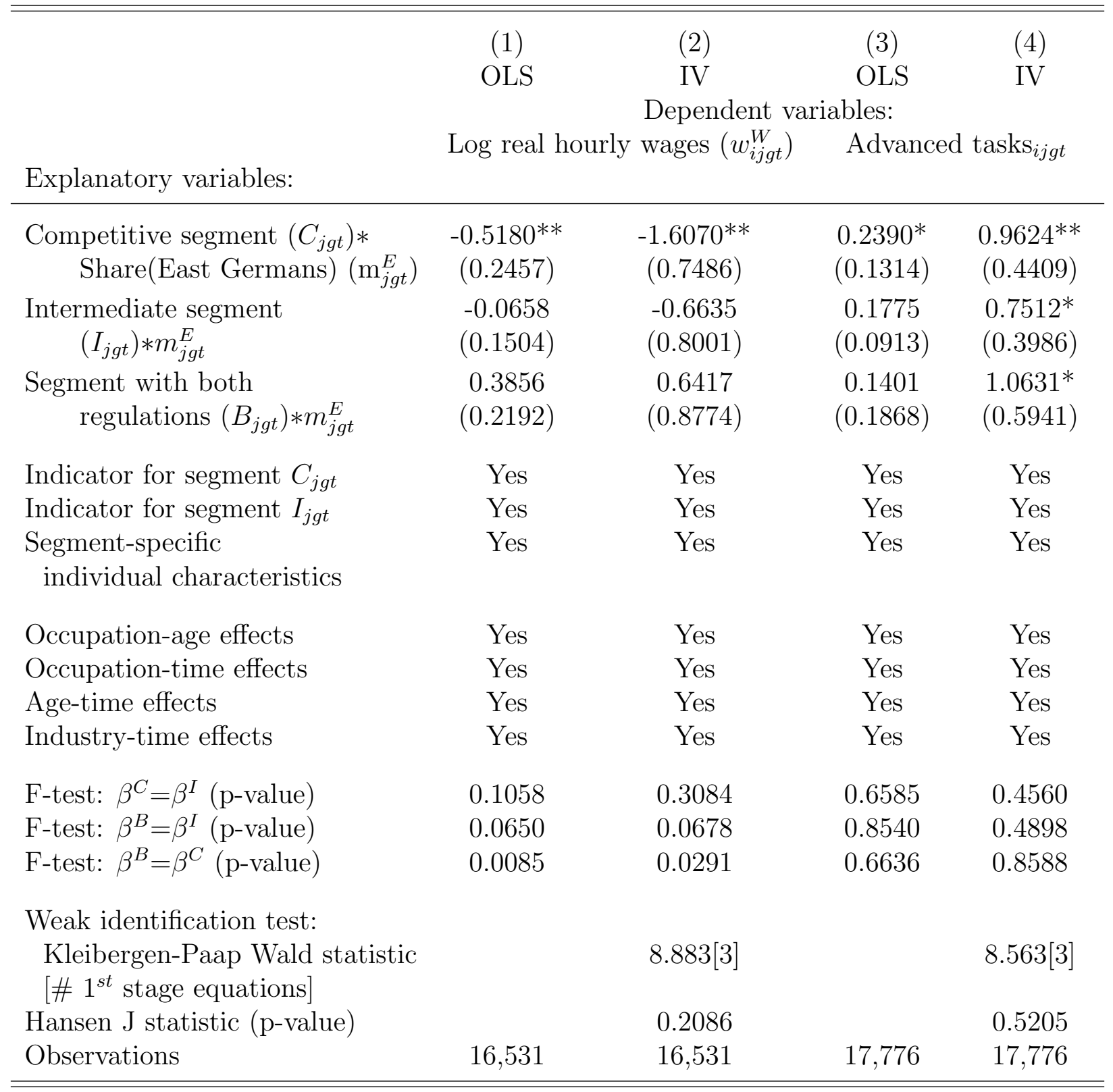

Notes: In columns 1 and 2, we provide OLS and IV estimates of wage equations for a sub-sample of 16,531 observations from the main sample described in Table 2 All included observations are for employees who did not experience an occupational change after 1989.

In columns 3 and 4 , we show OLS and IV estimates of equations explaining the extent to which employees perform advanced tasks such as designing, making plans, and monitoring machines. For these regressions, we use the main sample.

The set of excluded instruments in columns 2 and 4 is the same as in Table 3. Segment-specific individual characteristics are gender, age, age $^{2}$, tenure, and tenure ${ }^{2}$, all interacted with the dummies for the three segments $C_{j g t}, I_{j g t}$, and $B_{j g t}$.

Observations are weighted to take account of the sampling design. Robust standard errors in parentheses are clustered to allow for unrestricted correlation between observations in the same occupation-age cell. Statistical significance at the $1 \%(5 \%, 10 \%)$ level is indicated by $* * *(* * *)$. 


\section{Appendix for Internet Provision}

\section{A Historical and Institutional Background}

\section{German-German Migration after Reunification:}

In the main text, we describe the massive extent of the unanticipated wave of migration from East to West Germany following the sudden fall of the Berlin Wall on November 9, 1989. In addition, we explain that East German migrants are closer substitutes to native workers in West Germany than common immigrants are.

Here, we show that the large inflow of East Germans did not change the educational distribution of German employees in West Germany. The immigration rates that we observe in our survey data for the groups of high-, medium-, and low-skilled German employees are similar. More specifically, the share of East Germans among mediumeducated German employees in West Germany is 3.7 percent 82 Among German employees with high and low education, the shares are 3.5 percent and 3.7 percent, respectively. These figures compare well with those reported in D'Amuri et al. (2010) who use different data than we do. Descriptive statistics in Hunt (2006), again based on different data, also fit well. She reports that 69 percent of the East German migrants to the West German labor market have a medium level of education, 13 percent have a high level and 18 percent have a low level. In our data, 73.2 percent of all East German migrants have medium level of education, 12.8 percent have a high level and 14.0 have a low level. Among West Germans in the West German labor market, the shares with medium, high and low education are 72.3 percent, 13.6 percent and 14.1 percent, respectively ${ }^{83}$

While our interest is in the impact of interacting labor and product market regulation on wage effects of German-German migration after reunification, a large number of recent studies have analyzed labor market consequences of immigrant groups from other source regions to the West German labor market. Glitz (2012), for example, investigates the impact of immigration on labor market outcomes in West Germany in the time period 1996 to 2001. To deal with potential endogeneity of immigrants' choices of location, he exploits the fact that government authorities at that time followed exogenous rules in allocating ethnic German immigrants to West German labor market regions. During the 1990s, ethnic Germans immigrating from countries in Central and Eastern Europe or from the Soviet Union constituted the second largest group of immigrants to West Germany 84 In contrast to the East German migrants we are focusing on, ethnic German immigrants often arrived in Germany with poor language skills, and with vocational skills that only poorly matched the skill requirements of West German workplaces. As a result, the unemployment rate among ethnic Germans was very high.85 Other recent studies

\footnotetext{
${ }^{82}$ See Section 5 on the definition of high, medium, and low levels of education.

${ }^{83}$ All the descriptive statistics reported here, as well as the employment shares in the first paragraph of Section 2.1. are for the raw sample of 46,890 employees from the survey waves 1992 and 1999 who grew up in Germany, reside in West Germany, have German nationality and report the relevant data.

${ }^{84}$ Ethnic Germans are German nationals by descent who lived in a country in Central or Eastern Europe or in the Soviet Union before 1989. Similar to East Germans, ethnic Germans were prevented from migrating to West Germany before 1988/1989 due to the travel restrictions of their home countries. Only after the relaxation of these restrictions, could ethnic Germans migrate to West Germany.

${ }^{85}$ See, for example, Brück-Klingberg et al., 2007.
} 
on immigration into West Germany include Bonin (2005), Brücker and Jahn (2011), or Steinhardt (2011).

\section{Firm Entry Regulation in the German Trade and Crafts Code:}

The firm entry regulation in the German Trade and Crafts Code (GTCC; Gesetz zur Ordnung des Handwerks, Handwerksordnung, HWO) imposes substantial restrictions on firm entry into certain product markets, but not into others. The law that was in force during the observation period of our study, the 1990s, is that of 1965 (HWO, 1965), accompanied by additional legislation (Ergänzende Vorschriften zur Handwerksordnung). The GTCC version of 1965 is very similar to the first post-war version of 1953, and it underwent only minor updates up to the end of the 1990s. Most importantly, the set of regulated product markets remained virtually unchanged until the end of the 1990s.

According to the core rule establishing the firm entry restriction in the GTCC, individuals who want to be registered so that they can start a legally independent business in one of the regulated product markets (Eintragung in der Handwerksrolle) need to hold a relevant master craftsman certificate ( $\S 1$ and $\S 7$ HWO). During the 1990s, exceptions to this rule were possible for individuals with skills considered to be adequate, but such exceptions were only rarely granted ( $\$ 7-\S 9$ HWO, Monopolkommission 1998 and 2002). In addition, there are some educational degrees that were considered equivalent to the master craftsman certificate by law, but these degrees are similarly time-consuming to acquire ( $\$ 7 \mathrm{HWO}$ ). Non-incorporated firms can be registered if a fully liable owner who holds a relevant master craftsman certificate acts as manager. In the case of incorporated firms the managing director (Betriebsleiter) has to fulfill the requirement (see $\S 7 \mathrm{HWO}$ ).

Proponents of the firm entry regulation have argued that the regulated markets would work inefficiently or would fail without the regulation due to information asymmetries and external effects. They name as regulatory benefits the high quality of goods and services produced in the regulated markets, including consumer protection, and training activities providing skilled workers for other sectors of the economy. The German monopoly commission, other German institutions and EU institutions have opposed this (Deregulierungskommission 1991, Monopolkommission 1998 and 2002). They stress that individuals with a journeyman degree and several years of work experience in their occupation have a similar occupational qualification to those with a master craftsman certificate. In addition, many of the goods that are produced in the regulated markets are argued to be standard experience goods. Reputation effects, among other things, should work towards efficient market outcomes regarding product quality. Private training incentives of firms should foster the efficient provision of training activities. These institutions classify the firm entry regulation as a reason for higher product prices and lower production quantities. Firm entry, industry dynamics, and competition in the regulated markets are argued to be lower than without the regulation.

\section{Works Councils and Wage Bargaining:}

Establishment-level works councils are one core component of the German system of industrial relations, with other components being trade unions, employer associations, collective bargaining and firm-level co-determination. The main regulation regarding works councils is part of the Works Constitution Act (Betriebsverfassungsgesetz, BetrVG). 
The law that was in force during the observation period of our study, the 1990s, is that of 1972 (BetrVG, 1972).

The Works Constitution Act prescribes under which conditions a firm must establish a works council in an establishment, as well as the size and the composition of the works council. The law also stipulates that firms must pay for operating expenditures of their works councils. Office space and office personnel has to be provided by the firm $(\$ 40$ BetrVG), and a certain number of members of a works council have to be exempted from work so that they can devote all their work time to their council duties. The number of exempted council members depends on the council size, and thus on establishment size (§38(1) BetrVG).

As detailed in the main text, $\S 99$ and $\S 102$ BetrVG, among others, determine the rights and obligations of works councils in hiring, firing and pay scheme decisions on the establishment level. The information rights of works councils via the economic committees, as well as the involvement of works councils in additional firm management decisions are covered in $\S \S 106$ to 113. All these rulings contribute to the German system of establishment-level co-determination (betriebliche Mitbestimmung)

In the case of hiring and firing decisions, works councils act, to a large extent, independently of decisions made by unions and employers' associations in the context of collective wage bargaining.

In the case of wage agreements, works councils' decisions are, in principle, subordinate. Accordingly, we capture time-varying effects of industry-level wage bargaining on wages by including industry-time interactions into our model specifications, in addition to occupation-time interactions. In addition, note that works councils have become increasingly involved in wage bargaining since the 1980s, as industrial relations in Germany have become more flexible. Several characteristics of the German system of industrial relations have contributed to this development, spurred on by the decline in coverage. Firstly, the recognition of trade unions is at the discretion of the firm, and union contracts cover only the workers in those firms that recognize the relevant union(s) ${ }^{87}$ Secondly, contracts with unions set wage floors only. Finally, hardship or opening clauses (Härte- und Öffnungsklauseln) have been increasingly implemented into collective agreements, and the negotiation of establishment-level agreements has become more common (betriebliche Bündnisse zur Beschäftigungs- und Wettbewerbssicherung) (see, for example, Hassel, 1999, Hassel and Rehder, 2001, and Carlin and Soskice, 2009).

Altogether, wage bargaining has been decentralized to a large extent and the importance of works councils has increased relative to unions due to their role in the context of establishment-level co-determination. As Addison et al. (2013) put it: “..., issues that were formerly dealt with only under collective bargaining are increasingly being addressed within the domain of works councils". In a similar vein, Hassel and Rehder (2001) argue that the ordering between collective bargaining and establishment-level negotiation has changed, with collective agreements no longer superseding establishment-level agreements.

\footnotetext{
${ }^{86}$ Firm-level co-determination (unternehmerische Mitbestimmung) concerns incorporated firms in Germany, but this is not of core importance in our context.

${ }^{87}$ Individual workers in these firms are, however, covered independently of whether they are union members or not (Fitzenberger, Kohn and Wang, 2011).
} 


\section{B Data}

The "Qualification and Career Survey" was carried out by the Research Institute of the Federal Employment Service (Institut für Arbeitsmarkt- und Berufsforschung, IAB) and the German Federal Institute for Vocational Training (Bundesinstitut für Berufsbildung, $B I B B)$. The data for the three survey waves, referred to here as 1986,1992 , and 1999 for the sake of brevity, were collected during the winter months 1985/86, 1991/92 and 1998/99. Each wave covers about 30,000 observations on men and women. The sampling frame of the survey is the German population of employed individuals aged 16 to 65 with the selection of the sample following a random-route process at the household level. The targeted person per household is personally interviewed using a standardized questionnaire. In order to guarantee the representativeness of the survey data, the data set includes weighting factors. The first weighting factor accounts for the fact that the sampling probability in the chosen random-route process depends on household size. The second weighting factor adjusts core sample distributions (gender, age, occupational status, federal state, and size of municipality) to the corresponding distributions of the reference population to account for potentially selective non-response behavior of targeted persons. Typically, the reference statistics are taken from the German micro census, a 1 percent random sample of the German population.

The main sample with 17,776 observations is described in Table B.2. The sample covers employees in the West German labor market before and after reunification who grew up in West Germany, currently reside there and have German citizenship. As the survey coverage of foreigners varies between waves, we eliminate foreigners in the West German labor market from the sample. All employees considered report all data relevant to our empirical analysis, are between 25 and 54 years old, and work between 10 and 75 hours per week. We use detailed information on the current and training occupations of survey participants, which follows the 1988 classification with 334 three-digit occupational classes of the German Federal Statistical Office (Statistisches Bundesamt Deutschland) and the German Federal Employment Agency (Bundesagentur für Arbeit, $B A)$. The available data on the employers' industry affiliation follows the 2-digit 1993 European NACE classification, Revision 1.

As explained in the main text, we focus on individuals with medium level of education in accredited occupations. The share of employees with a low level of education varies between 17 and 11 percent across the three segments that we consider in our study. Highly skilled employees are strongly clustered into a few occupations: the share of highly educated employees is higher than 5 percent in 9 occupational classes only and all these are occupations without the firm entry regulation of the GTCC. ${ }^{88}$

\section{Wages:}

Our main dependent variable is the logarithm of the real hourly wage for West Germans in the West German labor market, measured in Euro at prices in the year 1991. To calculate the hourly wage of an employee we use the survey data on the monthly gross earnings

\footnotetext{
${ }^{88}$ The descriptive statistics in this paragraph are for the sample of 21,620 observations that results when applying all exclusion restrictions that we use for the main sample, except for the restrictions that exclude employees with a low or high level of education.
} 
of the employee, rank-ordered into 18 brackets, and divide the midpoint of the monthly earnings bracket by the employee's usual hours of work per month ${ }^{89}$ Hourly wages are deflated to 1991 prices using the consumer price index.

Table 1 indicates how the real hourly wages vary between the survey waves 1986 and 1999 for different employee groups in the West German labor market ${ }^{90}$ West German employees in product markets not subject to the GTCC entry regulation and in small establishments with weak worker influence on the firm's decision making earn, on average, 7.75 Euro per hour in 1986. In 1999, the real hourly wage is 9.24 Euro for this group of workers and, thus, higher than in 1986. West German employees in the same product markets, but in large establishments with strong worker influence, earn, on average, 9.29 Euro in 1986, that is, 1.54 Euro per hour more than employees in the same product markets, but in small establishments. In 1999, their real hourly wages is 11.37 Euro. The means are higher in the two corresponding segments with the GTCC entry regulation, although comparable in size, that is, between 8.37 Euro in 1986 and 11.57 Euro in 1999. Compared to the survey wave 1986, the wage dispersion is stable or lower in all segments of the West German labor market in 1992 and higher in 1999. East Germans earn less than West Germans in all survey waves and segments of the West German labor market.

\section{Immigration:}

The measures capturing immigration of East Germans to the West German labor market, as well as the instrumental variables that we use to allow for potentially endogenous migrant and employer decisions in our estimation equations explaining native wages, are described in Section 5 of the main text.

\section{Product and labor market regulation:}

Our main indicator for product market regulation, as well as the main indicator for labor market regulation, are fully described in the main text. Using these main measures of regulation, we distinguish between three segments of the West German labor market. 32.5 percent of the employees in our main sample are in the competitive segment $C_{j g t}$, 17.4 percent are in the segment with both regulations, $B_{j g t}$, and 50.1 percent in the intermediate segment, $I_{j g t}$.

To construct the alternative industry-level measure of product market regulation, we exploit the fact that our survey data also covers entrepreneurs, and provides information on their occupational activities, as well as the industries in which their firms are active. For each industry, we calculate the share of entrepreneurs who indicated that their entrepreneurial activity in 1986, 1992 or 1999 was in an occupation subject to GTCC entry regulation, and encode the industry-level measure with one in the 18 industries where the share is higher than one half, and zero in the 10 other industries in our main estimation sample 91 We merge the industry-level measure with our main sample of employees using the information that these employees provide on their employers' industry codes.

\footnotetext{
${ }^{89}$ Comparable procedures are often applied and have been used, for example, by DiNardo and Pischke, 1997, or Entorf and Kramarz, 1997.

${ }^{90}$ The wage variation across time and occupation-age cells per segment is described in section 5 , and shown in Table B.3 in Appendix B.

${ }^{91}$ The 28 industries represent either individual two-digit industry classes of the 1993 European NACE classification, Revision 1, or aggregated 2-digit classes.
} 
As mentioned in Section 3.1, the employer size distribution in regulated and unregulated product markets is similar. Appendix Table B.1 shows for both groups that about 74 percent of all workers are in small or medium-sized establishments with between 5 and 499 employees. The share of workers in micro establishments is 8.09 percent in regulated product markets, and, thus, lower than the share of 11.65 in unregulated ones. The share of workers in large establishments is greater with 17.81 percent versus 14.30 .

\section{Further demographic and work-related variables:}

To capture influences of individual heterogeneity on wages in our main regressions, we use the following variables: age in years at the survey date, gender which we code with one for men and zero for women, and tenure with the current employer. The tenure measure is based on survey participants' answers to the following question: "In which year did you start working for your current employer?". We define tenure as the survey year minus the year in which the survey participants started to work for their current employer. Our measure of establishment size distinguishes between seven size classes: (1) 1 to 4 employees, (2) 5 to 9 employees, (3) 10 to 49 employees, (4) 50 to 99 employees, (5) 100 to 499 employees, and (6) 500 to 999 employees, and (7) 1000 or more employees. In Section 6.3 we also use information on the activities that employees perform at the workplace (see also Spitz-Oener, 2006). The advanced task variable that we use is a share reflecting the number of the following five advanced tasks that an individual performs: designing, making plans, restoring, servicing machines and equipping machines. 
Table B.1: Employer size distribution across product market groups

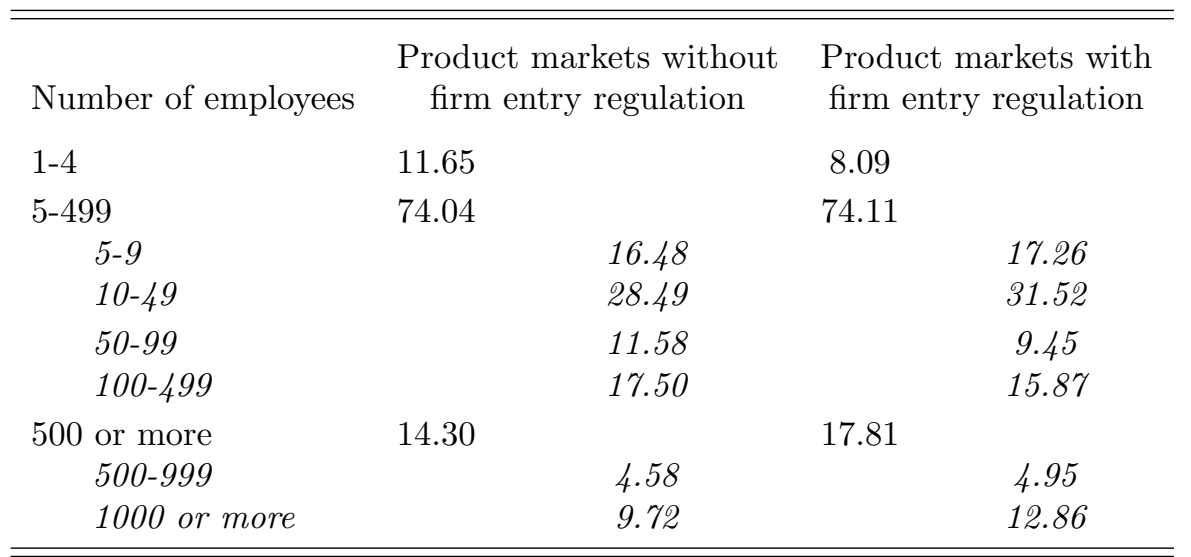

Notes: In this table, we show the distribution of employees in the West German labor market across establishment size classes in product markets with GTCC firm entry regulation and product markets without it. The calculations are based on a sample of 18,928 employees who participated in the survey waves 1986, 1992 or 1999, grew up in East or West Germany, reside in West Germany, have German citizenship, work between 10 and 75 hours per week, are between 25 and 54 years old, have a medium level of education, and report all data relevant to our study. Excluded are employees in the public sector, in non-profit organizations or the mining and quarrying sector, and in occupations that are not accredited by the BMBF and the BIBB. 
Table B.2: Definitions of variables and descriptive statistics

\begin{tabular}{|c|c|c|c|}
\hline Variable & Definition & $\begin{array}{l}\text { Mean/ } \\
\text { share }\end{array}$ & $\begin{array}{l}\text { Standard } \\
\text { deviation }\end{array}$ \\
\hline Wage $_{i j g t}$ & $\begin{array}{l}\text { real hourly wage of medium educated employee } i \text { in } \\
\text { Euro at year } 1991 \text { prices }\end{array}$ & 9.59 & 4.28 \\
\hline Immigration rate $_{j g t}$ & $\begin{array}{l}\text { share of East Germans in the medium-education } \\
\text { occupation-age-time cell } j g t \text { of the West German } \\
\text { labor market, taking values between } 0 \text { and } 1\end{array}$ & 0.02 & 0.04 \\
\hline Number of immigrants ${ }_{j g t}$ & $\begin{array}{l}\text { number of East Germans in the medium-education } \\
\text { occupation-age-time cell jgt of the West German } \\
\text { labor market }\end{array}$ & 1.54 & 2.88 \\
\hline $\begin{array}{l}\text { Pool(East Germans with } \\
\text { relevant training })_{j g t}\end{array}$ & $\begin{array}{l}\text { weighted pool of East Germans in medium-education } \\
\text { age-time cell } g t \text { in East or West Germany with a } \\
\text { vocational training relevant to occupation } \mathrm{j}\left(p_{j g t}^{E}\right)\end{array}$ & 15.57 & 17.15 \\
\hline $\begin{array}{l}\text { Pool(East Germans with } \\
\text { training in } j, \text { weighted }_{j g t}\end{array}$ & $\begin{array}{l}\text { weighted pool of East Germans in medium-education } \\
\text { age-time cell } g t \text { in East or West Germany with a } \\
\text { vocational training in occupation } \mathrm{j}\left(p_{j g t}^{E, 1}\right)\end{array}$ & 4.96 & 7.16 \\
\hline $\begin{array}{l}\text { Pool(East Germans with } \\
\text { training in } j, \text { unweighted }_{j g t}\end{array}$ & $\begin{array}{l}\text { unweighted pool of East Germans in medium-education } \\
\text { age-time cell } g t \text { in East/West Germany with } \\
\text { vocational training in occupation } \mathrm{j}\left(p_{j g t}^{E, 2}\right)\end{array}$ & 8.77 & 11.94 \\
\hline Firm entry regulation $_{j}$ & $\begin{array}{l}\text { 1: firm entry regulation of the German Trade and } \\
\text { Crafts Code in occupation } j, 0 \text { : otherwise }\end{array}$ & 0.40 & \\
\hline Worker influence $_{i j g t}$ & $\begin{array}{l}\text { 1: strong worker influence on decision-making of } \\
\text { firms, i.e. worker in establishment of } \geq 50 \text { employees, } \\
\text { 0: weak worker influence }(<50 \text { employees })\end{array}$ & 0.45 & \\
\hline Establishment size $_{i j g t}$ & $\begin{array}{l}\text { Size of the employing establishment in seven size } \\
\text { classes }(1-4,5-9,10-49,50-99,10-499,500-999, \geq 1000)\end{array}$ & 3.71 & 1.77 \\
\hline Advanced tasks $i j g t$ & $\begin{array}{l}\text { share of advanced tasks, i.e. designing, making plans or } \\
\text { monitoring machines, of all tasks performed by } i\end{array}$ & 0.18 & 0.25 \\
\hline Gender $_{i j g t}$ & 1: male, 0 : female & 0.64 & \\
\hline Age $_{i j g t}$ & age of employee $i$ in years at the survey date & 37.32 & 8.28 \\
\hline Tenure $_{i j g t}$ & years of work for current employer & 11.52 & 8.17 \\
\hline
\end{tabular}

Notes: This table provides non-weighted descriptive statistics for the main sample of 17,776 employees. All these employees participate in the survey waves 1986, 1992 or 1999, grew up and currently reside in West Germany, have German citizenship, work between 10 and 75 hours per week in West Germany, are between 25 and 54 years old, have a medium level of education, and report all the data relevant to our study. Excluded are employees in the public sector, in non-profit organizations or the mining and quarrying sector, and in occupations that are not accredited by the BMBF and the BIBB. In addition, we excluded all occupationage-time cells with less than 5 employees fulfilling the previously mentioned exclusion restrictions. 
Table B.3: Distribution of West Germans' real hourly wages in West Germany

\begin{tabular}{lccc}
\hline \hline Segments of the & \multicolumn{3}{c}{ Survey waves } \\
West German labor market & 1986 & 1992 & 1999 \\
& median of natives' average real hourly wage \\
& at the occupation-age-time level \\
& $(10$-percent percentile; 90-percent percentile) \\
Competitive segment without product & 7.8471 & 9.0982 & 9.5402 \\
and labor market regulation & $(6.0649 ; 10.3743)$ & $(6.6428 ; 12.1344)$ & $(6.9104 ; 13.3069)$ \\
Intermediate segment & 8.6552 & 9.8702 & 10.0294 \\
& $(6.6389 ; 11.0630)$ & $(7.5603 ; 12.4880)$ & $(7.5016 ; 13.0515)$ \\
Segment with product and labor & 8.8270 & 10.2799 & 10.8333 \\
market regulation & $(7.3697 ; 10.7340)$ & $(8.4869 ; 12.4832)$ & $(8.7485 ; 13.1514)$ \\
\hline \hline
\end{tabular}

Notes: In this table, we describe the sample distribution of the real hourly wages of West Germans in West Germany in 1991 Euro per survey wave and per segment. In each class, we display the median, the 10-percent as well as the 90-percent percentile of the real hourly wage of West Germans, averaged at the occupation-age-time level. The calculations are based on the main sample described in Table B.2. 
Table B.4: Distribution of the share of East German employees in West Germany

\begin{tabular}{lccc}
\hline \hline $\begin{array}{l}\text { Segments of the } \\
\text { West German labor market }\end{array}$ & 1986 & Survey waves & 1999 \\
& \multicolumn{2}{c}{$\begin{array}{c}\text { median of the share of East Germans } \\
\text { at the occupation-age-time level }\end{array}$} \\
& \multicolumn{2}{c}{$(10$-percent percentile; 90 -percent percentile) } \\
Competitive segment without product & 0 & 0.0138 & 0.0388 \\
and labor market regulation & $(0 ; 0)$ & $(0 ; 0.0574)$ & $(0 ; 0.1056)$ \\
Intermediate segment & 0 & 0.0095 & 0.02914 \\
& $(0 ; 0)$ & $(0 ; 0.0839)$ & $(0 ; 0.0906)$ \\
Segment with product and labor & 0 & 0.0220 & 0.0340 \\
market regulation & $(0 ; 0)$ & $(0 ; 0.1108)$ & $(0 ; 0.0791)$ \\
\hline \hline
\end{tabular}

Notes: In this table, we describe the sample distribution of the share of East Germans in West Germany per survey wave and per segment. In each class, we display the median, the 10-percent as well as the 90-percent percentile of the share which is measured at the occupation-age-time level. The calculations are based on the main sample described in Table B.2. 


\section{Additional Estimation Results}

In the main text, we briefly refer to robustness tests summarized in Table C.1. Here, these are explained in greater detail.

As discussed in Section 6.2 and Footnote 65, the results in Rows 1 and 2 of Table C.1 indicate that our main findings in Columns 1 and 3 of Table 3 are robust towards using the number of immigrants $E_{j g t}$ instead of the immigration rate $m_{j g t}^{E}$ as main explanatory variable. In Rows 3 to 6 we show robustness towards eliminating individual characteristics as explanatory variables, and to adding group-specific age-gender and tenure-gender interactions.

In the case of an alternative encoding of our instrumental variable we find qualitatively similar results as in Column 3 of Table 3, and we refer to this in Section 6.2. In Row 7, we use the alternative set of four excluded instruments involving the pool of all employees in age-group $g$ and time period $t$ who work in East or West Germany, who grew up in East Germany and have vocational training in occupation $j$. We introduced that pool measure in Footnote 59 and denoted it by $p_{j g t}^{E, 1}$. In Row 8, we use the alternative set of instruments based on the unweighted variant of the pool measure $p_{j g t}^{E, 1}$, denoting it by $p_{j g t}^{E, 2}$.

In Section 6.3 and Footnote 76, we mention the estimation results in Rows 9 to 12. First, we re-estimate our main model specifications of Columns 1 and 3 in Table 3 on the subsample covering all 7,157 workers in medium-sized establishments with 10 to 99 employees and find confirmation for our main findings in Rows 9 and 10. In Rows 11 and 12, we show that our main empirical pattern is confirmed, even more pronounced when re-estimating on the sub-sample of 15,820 workers not working in medium-sized establishments with 50 to 99 employees. The latter results indicate that our main findings do not depend on the inclusion of the establishment size class where the proportion of establishments with a works council is at least 16.7 percentage points lower than in higher size classes, where the shares are between 84.4 and 100 percent (Addison et al., 1997).

In Rows 13 and 14 we provide the results from re-estimating our main model specifications on the sub-sample of 13,701 workers where the job tenure data indicates no job change after 1988. The results confirm the previously reported differences in native wage responses to immigration across different segments, suggesting that these are not driven by differential job mobility patterns of West Germans (see also Section 6.3).

Finally, we restrict our estimation sample to the 8,883 workers in the group of industries that produce tradable goods, following the definition of Hanson and Slaughter (2002). Re-estimating on that sub-sample, we find - in line with Dustmannand Glitz (2013) that the unexpected wave of East Germans entering the West German labor market has no significant average effect on the wages of West Germans ${ }^{92}$ When we allow the immigration effects to differ across labor market segments within the industries that produce tradable goods, we observe the same kind of heterogeneity in native wage reactions to the immigration of similar workers as for our full estimation sample (see Rows 15 and 16). Importantly, this finding indicates that the mechanism which generates the heterogeneity in native wage reactions to immigration that we focus on is a different one than the one

\footnotetext{
${ }^{92}$ The OLS coefficient estimate (standard error) is 0.0547 (0.1665) and the IV coefficient estimate (standard error) is 0.1995 (0.9676).
} 
investigated by Dustmann and Glitz (2013). Their focus is, among others, on explaining the differences in the absorption of labor supply shocks across the tradable and nontradable sectors. Steinhardt (2011) reports differences in wage effects across occupations in manufacturing, primary and secondary services with the wage effect in primary services being strongest and negative. Taking his findings into account, we also re-estimate our main model specifications on the sub-sample without occupations in primary services and again find the heterogeneity in wage effects that we focus on. 
Table C.1: Further alternative model specifications

Dependent variable:

Log real hourly wages $\left(w_{i j g t}^{W}\right)$

$$
C_{j g t} * \mathrm{~m}_{j g t}^{E} \quad \begin{array}{cll}
\text { Main explanatory variables: } & \text { F-test: } \\
I_{j g t} * \mathrm{~m}_{j g t}^{E} & B_{j g t} * \mathrm{~m}_{j g t}^{E} & \beta^{B}=\beta^{C}
\end{array}
$$

Coefficient (Standard error): $\quad$ (p-value)

(1) OLS $-0.0109 * * *(0.0026) \quad-0.0061(0.0035) \quad 0.0076(0.0051) \quad 0.0010$

$\begin{array}{llllllll}(2) & \text { IV } & -0.0134^{* *} & (0.0058) & -0.0073(0.0083) & 0.0098(0.0097) & 0.0123\end{array}$

$\begin{array}{llllllll}\text { (3) } & \text { OLS } & -0.6309 * * & (0.2511) & -0.0983(0.1508) & 0.3422(0.2375) & 0.0061\end{array}$

$\begin{array}{llllll}\text { (4) IV } & -1.8487^{* * *}(0.7121) & -0.4276(0.7219) & 0.9479(0.7856) & 0.0032\end{array}$

$\begin{array}{lllllll}(5) & \text { OLS } & -0.7137^{* *}(0.2187) & -0.0729(0.1444) & 0.3137(0.2177) & 0.0013\end{array}$

$\begin{array}{lllllll}(6) & \text { IV } & -1.4920^{*} & (0.6480) & -0.4076(0.7259) & 0.8492(0.8108) & 0.0092\end{array}$

$\begin{array}{lllllll}\text { (7) } & \text { IV } & -2.2183^{* *}(1.0087) & -2.0448(1.4940) & 0.6149(1.5956) & 0.0354\end{array}$

$\begin{array}{lllllll}(8) & \text { IV } & -2.5315^{*} & (1.3598) & -2.3022(1.6385) & -0.0519(1.7496) & 0.0769\end{array}$

$\begin{array}{llllll}\text { (9) OLS } & -0.8303^{* * *}(0.3111) & -0.1015(0.2350) & 0.5815(0.3017) & 0.0016\end{array}$

$\begin{array}{lllllll}(10) & \text { IV } & -2.1141^{* *}(0.8867) & -0.0863(1.1424) & 0.3228(1.4789) & 0.0644\end{array}$

$\begin{array}{llllll}\text { (11) OLS } & -0.6181^{* * *}(0.2247) & -0.0702(0.1429) & 0.2358(0.2326) & 0.0099\end{array}$

$\begin{array}{llllll}(12) & \text { IV } & -1.9668^{* * *}(0.7504) & -0.1354(0.7580) & 0.4896(0.8278) & 0.0129\end{array}$

$\begin{array}{llllll}\text { (13) OLS } & -0.8115^{* * *}(0.2942) & -0.0528(0.1740) & 0.3060(0.2513) & 0.0259\end{array}$

$\begin{array}{lllllll}(14) & \text { IV } & -1.9052^{* *} & (0.9245) & -0.1388(1.0243) & 1.4086(1.1118) & 0.0092\end{array}$

$\begin{array}{llllll}\text { (15) OLS } & -0.8391^{* *}(0.4231) & -0.0125(0.2280) & 0.2788(0.2486) & 0.0054\end{array}$

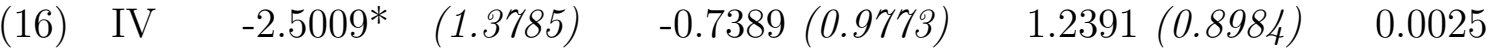

Notes: In this table, we summarize the results of the robustness tests referred to in the main text and described at the beginning of Appendix C). All regression equations include full sets of occupationage interactions, occupation-time interactions, age-time interactions, and industry-time interactions. We also include two segment indicators and individual characteristics (gender, age, age ${ }^{2}$, tenure, and tenure $^{2}$ ) that are interacted with the dummies for the three segments $C_{j g t}, I_{j g t}$, and $B_{j g t}$.

The p-values that are reported at the end of Rows 1 to 16 are for F-tests on the null hypothesis $\beta^{B}=\beta^{C}$. In Row 1 to 8 , we use the main sample of 17,776 observations (see also Table 2 , Section 5 and Appendix B. In Rows 9 and 10, we use the sub-sample covering the 7,157 employees in mediumsized establishments with 10 to 99 employees and in Rows 11 and 12 the one covering all 15,820 employees that are not in medium-sized establishments with 50 to 99 employees. The sub-sample used in Rows 13 and 14 includes the 13,701 workers where the job tenure data indicates no job change after 1988 and the one used in Rows 15 and 16 includes the 8,883 workers in the sector of tradable goods.

Observations are weighted to take account of the sampling design. Robust standard errors in parentheses are clustered to allow for unrestricted correlation between observations in the same occupation-age cell. Statistical significance at the $1 \%(5 \%, 10 \%)$ level is indicated by $* * *(* *, *)$. 
Table C.2: Alternative model specifications with additional explanatory terms, depending on establishment size

\begin{tabular}{|c|c|c|c|c|}
\hline Explanatory variables: & $\begin{array}{c}(1) \\
\text { OLS } \\
\text { Dependent }\end{array}$ & $\begin{array}{c}(2) \\
\text { IV) } \\
\text { variable: Lc }\end{array}$ & $\begin{array}{c}(3) \\
\text { OLS } \\
\text { real hourl }\end{array}$ & $\begin{array}{c}\text { IV } \\
\text { IV } \\
\text { vages }\left(w_{i j g t}^{W}\right)\end{array}$ \\
\hline $\begin{array}{l}\text { Competitive segment }\left(C_{j g t}\right)^{*} \\
\quad \text { Share(East Germans) }\left(\mathrm{m}_{j g t}^{E}\right)\end{array}$ & $\begin{array}{c}-0.6263^{* *} \\
(0.2495)\end{array}$ & $\begin{array}{r}-1.4798^{*} \\
(0.8116)\end{array}$ & & \\
\hline $\begin{array}{l}\text { Intermediate segment } \\
\qquad\left(I_{j g t}\right)^{*} \mathrm{~m}_{j g t}^{E}\end{array}$ & $\begin{array}{l}-.0134 \\
(0.2731)\end{array}$ & $\begin{array}{l}-0.3864 \\
(1.1799)\end{array}$ & & \\
\hline $\begin{array}{l}\text { Labor market segment with both } \\
\text { regulations }\left(B_{j g t}\right)^{*} \mathrm{~m}_{j g t}^{E}\end{array}$ & $\begin{array}{c}0.4119 \\
(0.4141)\end{array}$ & $\begin{array}{c}0.8306 \\
(1.6199)\end{array}$ & & \\
\hline Establishment $\operatorname{size}^{*} \mathrm{~m}_{j g t}^{E}$ & $\begin{array}{l}-0.0203 \\
(0.0624)\end{array}$ & $\begin{array}{l}-0.0185 \\
(0.2135)\end{array}$ & $\begin{array}{c}0.0099 \\
(0.0252)\end{array}$ & $\begin{array}{c}0.1477 \\
(0.1358)\end{array}$ \\
\hline Establishment size & $\begin{array}{c}0.0385^{* * *} \\
(0.0041)\end{array}$ & $\begin{array}{c}0.0385 * * * \\
(0.0062)\end{array}$ & $\begin{array}{c}0.0382^{* * *} \\
(0.0026)\end{array}$ & $\begin{array}{c}0.0351^{* * *} \\
(0.0038)\end{array}$ \\
\hline $\begin{array}{l}\text { Indicator for segment } C_{j g t} \\
\text { Indicator for segment } I_{j g t}\end{array}$ & $\begin{array}{l}\text { Yes } \\
\text { Yes }\end{array}$ & $\begin{array}{l}\text { Yes } \\
\text { Yes }\end{array}$ & $\begin{array}{l}\text { No } \\
\text { No }\end{array}$ & $\begin{array}{l}\text { No } \\
\text { No }\end{array}$ \\
\hline $\begin{array}{l}\text { Individual characteristics } \\
\text { Segment-specific individual char. }\end{array}$ & $\begin{array}{l}\text { No } \\
\text { Yes }\end{array}$ & $\begin{array}{l}\text { No } \\
\text { Yes }\end{array}$ & $\begin{array}{l}\text { Yes } \\
\text { No }\end{array}$ & $\begin{array}{l}\text { Yes } \\
\text { No }\end{array}$ \\
\hline $\begin{array}{l}\text { Occupation-age effects } \\
\text { Occupation-time effects } \\
\text { Age-time effects } \\
\text { Industry-time effects }\end{array}$ & $\begin{array}{l}\text { Yes } \\
\text { Yes } \\
\text { Yes } \\
\text { Yes }\end{array}$ & $\begin{array}{l}\text { Yes } \\
\text { Yes } \\
\text { Yes } \\
\text { Yes }\end{array}$ & $\begin{array}{l}\text { Yes } \\
\text { Yes } \\
\text { Yes } \\
\text { Yes }\end{array}$ & $\begin{array}{l}\text { Yes } \\
\text { Yes } \\
\text { Yes } \\
\text { Yes }\end{array}$ \\
\hline $\begin{array}{l}\left.\text { F-test: } \beta^{C}=\beta^{I} \text { (p-value }\right) \\
\text { F-test: } \beta^{B}=\beta^{I}(\mathrm{p} \text {-value }) \\
\left.\text { F-test: } \beta^{B}=\beta^{C} \text { (p-value }\right)\end{array}$ & $\begin{array}{l}0.0368 \\
0.1272 \\
0.0120\end{array}$ & $\begin{array}{l}0.2288 \\
0.1518 \\
0.0768\end{array}$ & & \\
\hline $\begin{array}{l}\text { Weak identification test: } \\
\text { Kleibergen-Paap Wald statistic } \\
\text { [\# of first stage equations] }\end{array}$ & & $6.928[3]$ & & $93.410[1]$ \\
\hline Hansen J statistic (p-value) & & 0.542 & & \\
\hline Observations & 17,776 & 17,776 & 17,776 & 17,776 \\
\hline
\end{tabular}

Notes: In Columns 1 and 2, we show OLS and second stage IV estimates for model specifications that extend our main ones in Columns 1 and 3 of Table 3 by two additional explanatory variables, namely establishment size and its interaction with the share of East Germans in West Germany. In column 2, the set of instruments consists of the four interactions of the immigration pool measure with the worker groups $C_{j g t}, I .1_{j g t}, I .2_{j g t}$, and $B_{j g t}$ and the interaction with establishment size. In Columns 3 and 4 , we provide the estimates for model specifications with the two additional explanatory variables as in Columns 1 and 2 , but without segment-specific terms.

The estimation sample is our main sample of 17,776 observations (see also Table 2 Section 5 and Appendix B). Segment-specific individual characteristics are gender, age, age $^{2}$, tenure, and tenure ${ }^{2}$, all interacted with the dummies for the three segments $C_{j g t}, I_{j g t}$, and $B_{j g t}$.

Observations are weighted to take account of the sampling design. Robust standard errors in parentheses are clustered to allow for unrestricted correlation between observations in the same occupation-age cell. Statistical significance at the $1 \%(5 \%, 10 \%)$ level is indicated by $* * *(* *, *)$. 